This is an electronic version of an article published as: Warsh, C.K. \& Tinkler, P. (2007). In vogue: North American and British representations of women smokers in Vogue, 1920s-1960s. Canadian Bulletin of Medical History / Bulletin canadien d'histoire de la médecine, 24(1), 9-47.

Canadian Bulletin of Medical History / Bulletin canadien d'histoire de la médecine is published by the Canadian Society for the History of Medicine and is available online at:

http://www.cbmh.ca/index.php/cbmh/index.

This article is available at: http://www.cbmh.ca/index.php/cbmh/article/view/950/945. 


\title{
Conference Selections
}

\section{In Vogue: North American and British Representations of Women Smokers in Vogue, 1920s-1960s}

\author{
CHERYL KRASNICK WARSH \\ PENNY TINKLER
}

\begin{abstract}
The image of a cigarette in a woman's hand symbolizes independence, non-conformity and personal power, despite widespread awareness that smoking has serious health risks. Through a content analysis of North American and British editions of Vogue, we trace the representation of women smokers from the 1920s-1960s. Vogue located the cigarette within the culture of the feminine elite. We explore the place of cigarette smoking within the constellation of behaviours and appearances presented as desirable characteristics of elitism, through the themes of lifestyle, "the look," and feminine confidence. We chart these themes' transformations over time and national contexts.

Résumé. L'image d'une cigarette dans une main de femme symbolise l'indépendance, le non-conformisme et le pouvoir personnel, malgré la reconnaissance du fait que fumer comporte de sérieux risques pour la santé. Par une analyse de contenu des parutions américaines et britanniques de Vogue, nous retraçons l'évolution de la représentation des fumeuses de la décennie 1920 jusqu'à la décennie 1960. Vogue situe la cigarette dans une culture féminine d'élite. Nous explorons la place du tabagisme dans la constellation de comportements et d'apparences associés à l'élitisme et présentés comme désirables, à travers les thèmes $\mathrm{du}$ mode de vie, $\mathrm{du}$ «look» et de l'assurance féminine. Nous faisons ressortir les transformations de ces thèmes dans le temps et selon les contextes nationaux.
\end{abstract}

Cheryl Krasnick Warsh, Department of History, Malaspina University-College, Nanaimo, B.C.

Penny Tinkler, Department of Sociology, University of Manchester, U.K. 
By the beginning of the 21st century, the image of a cigarette in the hand of an elegant woman resonates in Western popular culture as a symbol of independence, non-conformity, and personal power. ${ }^{1}$ This representation co-exists with the knowledge that tobacco smoking has serious and multiple health risks and shortens life expectancy. ${ }^{2}$ Amid these mixed messages girls and young women remain the fastest growing segment of the smoking population. ${ }^{3}$ They also (predictably) are targeted by tobacco companies in advertising campaigns. Was this always the case? In this study, we trace the representation of women smokers from the 1920s, when female smoking, if not widespread, was becoming more acceptable. At this time, tobacco companies were often cautious about directly appealing to women in advertisements, ${ }^{4}$ although there were positive representations of female smokers in other forms. ${ }^{5}$ We end our study in the 1960s, when female smoking had become normalized behaviour, and tobacco advertisements directed at this market were routine. We have selected Vogue magazine, a popular haute couture fashion magazine, for analysis, since it produced both a North American edition and a British edition in this time period, to render a transatlantic comparison of the images presented. ${ }^{6}$

From the launch of Vogue, cigarettes appeared in the hands of female models, cautiously at first and then regularly and even brazenly. At a time when few women smoked in America and Britain,7 Vogue located the cigarette firmly within the culture of the feminine elite. This paper explores the place of cigarette smoking within the constellation of behaviours and appearances presented as desirable characteristics of elitism, through the themes of lifestyle, "the look" (including ideal body shape and age) and feminine confidence. We demonstrate how, on both sides of the Atlantic, the smoking culture of the feminine elite was characterized by sophisticated pleasure seeking and the slimness and poise of the woman smoker. ${ }^{8}$ However, these were not static themes and our paper charts their transformations over time. There were also differences in the representations of the elite smoking cultures of American and British women. The relative values of maturity and youthfulness differed by location and shifted over time; more generally the timing of the emergence of themes and the emphasis attached to them were dependent upon national context.

\section{SMOKING AND THE IN-VOGUE LIFESTYLE}

Vogue was established in 1892 as a weekly fashion and society magazine for a small group of New York's social elite. Condé Nast, a business manager at Collier's magazine, purchased Vogue (as well as House and Garden) in 1909, and set out to create a fortune by targeting a select, rather than a mass audience, or as he recounted, "If you had a tray 
with 2,000,000 needles on it and only 150,000 of these had gold tips which you wanted, it would be an endless and costly process to weed them out.... But if you could get a magnet that would draw out only the gold ones what a saving!" Vogue was to be the magnet attracting a wealthy audience to the advertisers of luxury goods. ${ }^{9}$ Nast published French and as well as British editions of Vogue, although the French version was halted during the German occupation in World War II. By 1962, there were five foreign editions, the most notable being Novita, the Italian version published in Milan. ${ }^{10}$

The founding edition in 1912 of Nast's Vogue, ${ }^{11}$ which, like other American mass circulation magazines, had significant readership in Canada, ${ }^{12}$ targeted an upper-class/upper-middle-class female market. To reach this audience, the editors offered production values which surpassed many other popular magazines. Under the supervision of art directors Heyworth Campbell and Dr. Mehemmed Fehmy Agha, US Vogue "was clean, modern, and pleasing to the eye," while the contributions of leading photographers like Edward Steichen rendered Vogue's pages "artistic and handsome."13 Following the success of US Vogue in England during the early years of the Great War, Nast launched a British edition nicknamed "Brogue." 14 Combining fashion material from the US with "local" features, British Vogue presented the same stylish face as its US counterpart. The face of "Brogue" was, however, not uncontested. While Nast saw fashion as the hallmark of Vogue, Dorothy Todd, British editor from 1922-26, envisaged British Vogue as a leading literary and artistic magazine. ${ }^{15}$ In the tussle that ensued, fashion won, Todd was dismissed, and British Vogue was brought into line with its US counterpart.

Similar to other women's magazines, Vogue's senior management was divided by gender; Nast was the publisher, and Edna Woolman Chase was the founding editor, while at the local level, women usually edited the different editions while men were the business managers. ${ }^{16}$ Although ultimate authority rested with Nast, gender dynamics were often complicated within this publishing structure. The complexity is clearly revealed by the experience of Chase when she was sent by Nast to London in the 1920s to take over British Vogue from Dorothy Todd. ${ }^{17}$ Chase describes some "difficult patches" with senior men in the British production team, including the head of advertising and the business manager whom she recalls were not accustomed to women in authority. Confronted with numerous obstructions, Chase drew on Nast's support to assert her authority over the British team, and when the men attempted to circumvent her instructions by using the exclusively male board of directors, Nast made Chase a director.

As long as editors worked with Nast's vision, the editors had considerable authority over their particular editions of Vogue. According to a reviewer of her autobiography, Chase's "judgment, taste [and] uncom- 
promising standards of perfection were the real heart of Vogue's success. She stood up to advertisers with the courage of a small, ferocious lion, flatly refus[ing] to give editorial mention to any merchandise she thought in bad taste...." Chase, who began her employment at Vogue in the 1890s, would spend almost 60 years at the magazine, relinquishing her authority in 1952. ${ }^{18}$ Later US Vogue editors, most notably Grace Mirabella, Diana Vreeland, and Anna Wintour, also became legendary figures in the publishing world, due in large part to their editorial freedom. This management style and high production standards apparently were successful because the magazine's market demographics appealed to advertisers. ${ }^{19}$

That Vogue targeted an upper-class audience was evident not only in its haute couture fashion spreads and elite dining and club reviews but in its adverts, particularly in the earlier years, for private schools and summer camps. ${ }^{20}$ However, given the relatively small size of the elite and the potentially huge market for the aspiring (or fantasizing) elite, the journal was not exclusionary. While most readers could not purchase Parisian fashions, they could order the highly popular (and still extant) Vogue patterns and create their own imitations. With respect to the advertised products, readers may not have been able to buy haute couture from Saks department store, but they could purchase gloves, purses, hosiery, scarves and other less pricey items from the high-end retailers, as well as similarly styled imitations from their competitors. The British edition of Vogue, launched in 1916, was similarly for the feminine elite. At a time when many of the British gentry and aristocracy were experiencing straitened circumstances, this readership included the most affluent of the old upper class as well as the newly rich that had prospered from the war-time boom in the economy. ${ }^{21}$ Unlike its American counterpart, British Vogue did not begin to cater for women on more modest incomes until the Depression years.

On both sides of the Atlantic, one of the basic features of Vogue was the double or multipaged fashion spread, highlighting (especially in the early years) Parisian haute couture. This was an area where the cigarette first became established as a regular feature and demonstrated that cigarette smoking already was a widespread or at least accepted practice among elite women. As early as the 1880s, Montreal newspapers ran items on European royalty and university co-eds who smoked. ${ }^{22}$ In the same decade, the New York Times reported that 12 "well-bred" students were caught smoking at the Wilson Female Seminary in Massachussetts, while anti-tobacco advocate Mrs. John A. Logan complained that "it had become customary in certain sets for women to exchange jewelencrusted cigarette cases and costly holders as gifts." ${ }^{23}$ Canadian and American observers concurred that society women in their countries modelled their smoking habits upon the practices of upper-class British 
and European women. Though pursued out of the public eye, the cigarette habit grew in popularity among upper- and upper-middle-class British women in the late 1880s and by the 1890s British retailers were marketing expensive "ladies" cigarettes, as well as a range of feminine smoking paraphernalia, to the select audience who could afford them. On the eve of the Great War, cigarette smoking was an established female practice amongst Britain's social elite. ${ }^{24}$

Figure 1

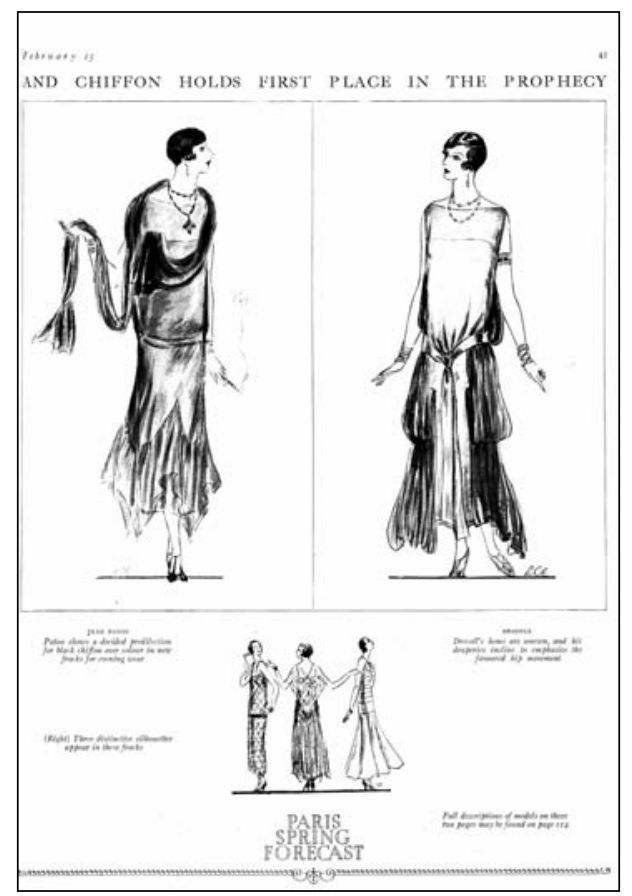

“Paris Spring Forecast," US Vogue (15 February 1924), p. 41.

Vogue's images instructed women how to handle those cigarettes. A standard fashion pose in the spreads of the first editions of Vogue was of a drawn figure, facing frontward or backwards, with one hand on hip and the other elbow bent, palm turned upward. Occasionally that hand would hold a feather, a purse or some other prop. By 1924, however, fashion illustrators discovered that the cigarette was a superbly light and unobtrusive prop which nonetheless created a powerful connection between smoking and sophistication. In a 1924 spread of US Vogue, "Paris Spring Forecast," (Figure 1) where there were several models in a pictorial, at least one smoked. ${ }^{25}$ The text accompanying these spreads described an upper-class, sophisticated, European-influenced lifestyle. 
Smoking women were identified as European or American "aristocrats," such as the "Duchess de Gramont." 26 Fashion spreads and advertising in British Vogue similarly portrayed women smokers of the 1920s wearing stylish and beautiful clothes. While smokers in fashion promotions represented only a small proportion of the great amount of advertising that appeared in Vogue at this time, the appearance of women smokers in this context was important. The alignment of smoking with high status couture houses established smoking as an exclusive, elegant, and sophisticated practice. The use of Society women as models in fashion features and adverts bestowed further status on smoking as the practice of the fashionable feminine elite as in an article illustrated by a picture of an elegantly dressed countess who smoked while reclining in "a Charvet negligee of apricot coloured silk." 27

The sophisticated affluence of the woman smoker also was conveyed in cigarette advertisements in British Vogue from 1919. Adverts for handmade ladies cigarettes, often scented to individual taste, featured in a regular small adverts page until the late 1920s. Perfumed Moments were

The daintiest and most elegant cigarette ever offered to My Lady. A perfumed silver tipped cigarette hand made from carefully selected highest grade Virginian Tobacco. Perfumed by a special process giving a subtle and exquisite aroma...this process enables us to perfume our cigarettes to individual taste. When ordering name your favourite perfume and your cigarettes will be delicately scented to your fancy. 28

Full-page colour adverts for the mass-produced De Reszke brand of cigarettes, which appeared on the inside cover pages of British Vogue in 1919 and 1920, also targeted the elite woman smoker but portrayed her in more public settings of Society leisure such as at a Lords cricket match, an exhibition at the Royal Academy, and punting on the Thames (Figure 2). Glamorous associations were fuelled further by adverts featuring leading ladies of the stage..$^{29}$

Although cigarette smoking was evident throughout US Vogue issues of the 1920s, tobacco adverts themselves were not yet frequent, and those that were published were tentative and coy concerning the targeting of female smokers. This likely was due to the tobacco industry's concern to avoid antagonizing the powerful anti-cigarette lobby. ${ }^{30}$ One of the earliest advertisers, Pall Mall, evidenced this. The adverts apparently were directed to men, but the text was ambiguous. There was a woman present in every Pall Mall advert (although not smoking), and the text was directed most obviously at men: "after your coffee, when you've snuggled down in your easy chair to read, relax or chat-light up a real Pall Mall, ... the only smoke for the Luxury Hour-that treasured hour after the day's work when a man's in the mood for Life's best." 31 Despite the male address, the advert drew attention to a new and smaller size Pall Mall cigarette. In a sister advert, in which a cigarette-girl 
was selling to two male diners, this smaller Pall Mall was described in decidedly feminine terms, "The same regal quality cigarette-slightly smaller in girth... at a purse-easy price." 32

Figure 2

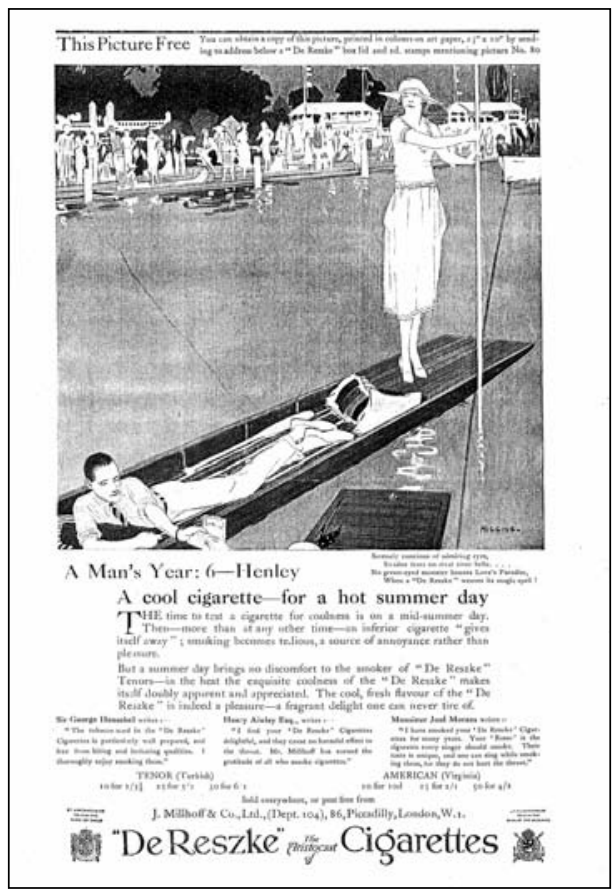

“De Reszke Cigarettes” advert, British Vogue (early July 1920), inside front cover.

By the thirties, American tobacco companies' appeals to female smokers were in high gear. That smoking had become respectable and widespread by the 1930s was apparent in the cigarette adverts themselves, ${ }^{33}$ which had lost their coyness and directly targeted the US Vogue reader. The use of testimonials of "real life" sophisticates increasingly was common in both pictorials and advertisements (although testimonials themselves were a common 19th-century advertising feature, particularly with respect to patent medicines). ${ }^{34}$ Camels initiated its successful and widely disseminated testimonial series of wealthy women, with recognizable names like Dodge, Cabot, and Lodge. ${ }^{35}$ Whereas the smoking sophisticate was European in the 1920s, by the thirties she was a homegrown, specifically northeastern American socialite. The socialite Mrs. Kendall Lee Glaenzer appeared complete with solid gold Napoleonic cigarette case, in an elaborate Listerine toothpaste advert targeting "smoker's teeth." 36 This last was a startling (and rare) juxtaposition of the image of the wealthy sophisticate with the reality of the deleterious physical effects of smoking. 
Figure 3

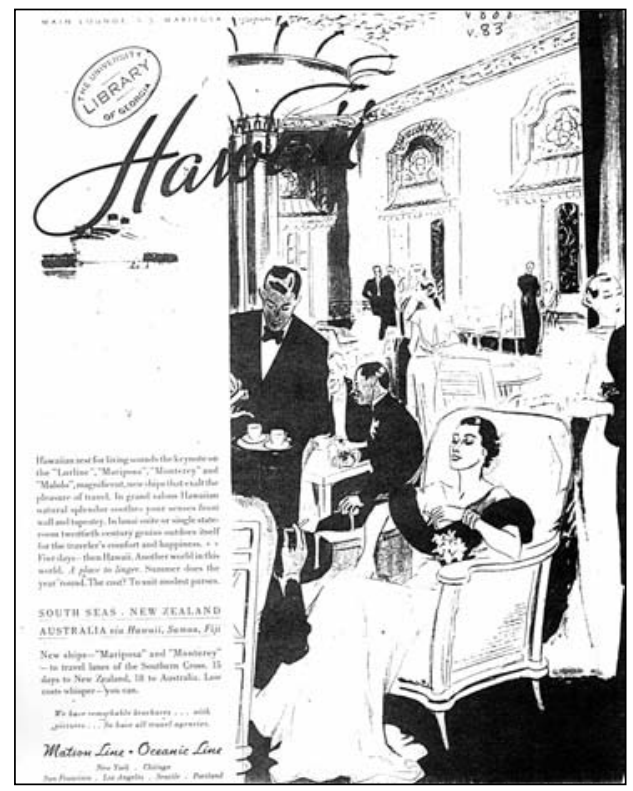

"Hawaii-Matson Line" advert, US Vogue (1 January 1934), inside front cover.

The opulent and sophisticated pleasures of the smoking elite were paraded throughout the 1930s. In the inside cover of the first issue of 1934's US Vogue, an advert selling Matson cruise ships displayed a woman in a first-class cocktail lounge/ballroom smoking with an escort (Figure 3). ${ }^{37}$ Expensive fashion pictorials, which now included photographs, had many women with cigarettes and lighting other women's cigarettes..$^{38}$ With the much-celebrated demise of Prohibition, the pictorials and society photos were awash with alcohol and cigarettes. A couple was photographed at New York's exclusive Waldorf Hotel, the woman clad in Cartier jewellery, holding a cigarette, and martini glass. ${ }^{39}$ In a didactic essay on becoming a glamorous smoker, the central place of the cigarette in high life was driven home, although this was more likely a fantasy for urban audiences in Depression America: "As the finale to a long walk in the rain, or a hard ride, or a day's shooting, a cigarette and a couch and an open fire can together achieve a certain ecstasy." 40 Overt instructions for aspiring sophisticates were offered through humorous and didactic means. "Tragedies of the current mode" included a cartoon drawing of a "smart" woman juggling muff, bag, gloves, cigarette, and cocktail. ${ }^{41}$ In an article on the proper presentation of and equipment for after-dinner drinking parties, a caption, "The Long Drink during Bridge," accompanied a photograph of a woman holding a highball glass and 
cigarette with holder at a card table..$^{42}$ Adverts for Spud cigarettes, a particularly foul-tasting brand promoted by the vaudevillian Fanny Brice, described the product as an acquired taste, like caviar. ${ }^{43}$

Figure 4

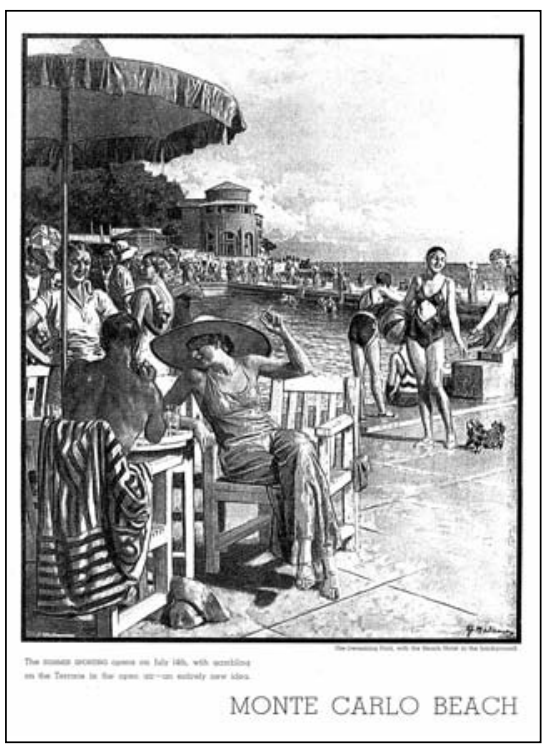

“Monte Carlo Beach," British Vogue (11 July 1934), p. 34.

In Britain as well, chic smokers in fashion adverts and features reinforced the association of smoking with affluent and fashionable lifestyles. Vogue women smokers played tennis, went cruising, played golf and, when in Monte Carlo, they gambled on the terraces (Figure 4). ${ }^{44}$ Women smokers donned Harrods jumpers for "smart luncheons or for cocktails" 45 and they hosted "smart" bridge parties. ${ }^{46}$ The location of smoking in the feminine high life was neatly portrayed in an advert for Wolsley fabrics in which two women, one smoking, stood amid their travel bags, golf clubs and furs, with an ocean liner visible in the distance. ${ }^{47}$ Occasionally, in photo spreads of "day to day life" in the upper echelons of society, named ladies were visible with cigarettes in hand. ${ }^{48}$ Reflecting the shifting fortunes of at least some British Vogue readers, less affluent women smokers were addressed as leading lifestyles that required "Smart fashions for limited incomes" 49 and "practical dressmaking." 50 Vogue's "economy wardrobe for the season," however, was not a lowbudget affair as graceful women smokers modelled an evening dress and a "long frock for formal afternoons, cinema and all manner of afternoon-into-evening occasions" (Figure 5). ${ }^{51}$ Cigarette advertisements for Player's cigarettes depicted elegant and refined young women smoking, 
but unlike the twenties the contexts were not usually highlighted. White suggests that during the interwar period British Vogue, like other upperclass magazines, felt compelled to introduce features that recognized the straitened circumstances of some readers. ${ }^{52}$ It is also likely that, after 1930, Vogue attempted to secure a broader readership in the context of the ascendancy of new middle- and lower-middle-class magazines and displacement of the Society papers. ${ }^{53}$ In Britain, the growth in importance of the respectable middle classes is apparent in cigarette advertising in other women's magazines. Society women were not the most lucrative market for tobacco manufacturers, or indeed manufacturers of other mass products..$^{54}$

Figure 5

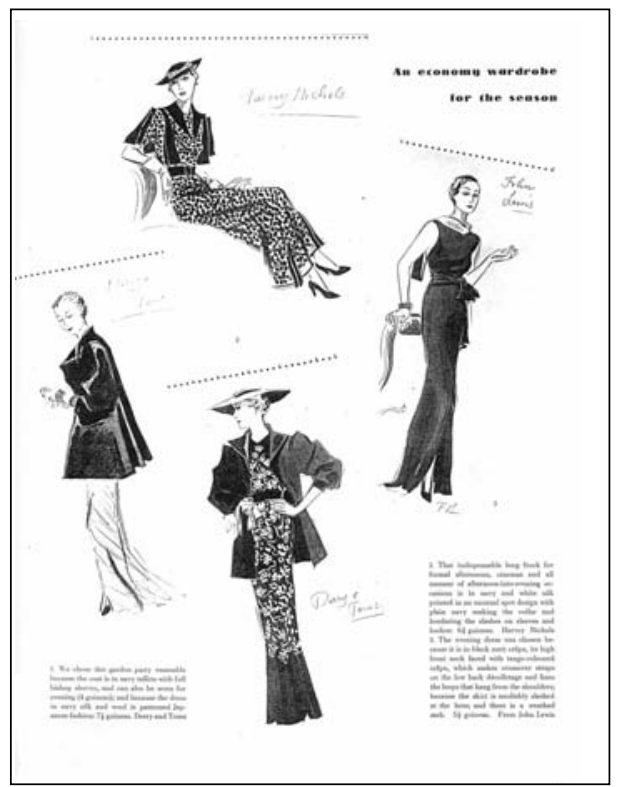

British Vogue (2 May 1934), p. 111.

In "The Nicotined Lady," published in the US Vogue in 1934, the role of smoking in the construction of feminine identity was spelled out clearly:

Seduction, Suspense, Sophistication. Find the play or the book...now written where the cigarette isn't a vital accessory to the feminine fact. Women smoking. Women laughing through the tenuous blue screen. Women's hands, languidly reaching for their cigarette-cases. Women pressing out a stub, meditatively, finally, their red nails so alive against the dying ash.... Smoking, for a woman, is an adornment, an opiate, a defence, a weapon, a concealment, depending on her inner chemistry....Wherever she goes, whatever she does, the little jewelled or lacquered case goes with her; to lunches, to business, to trysts. The striking 
of a match has become as unconscious a feminine gesture as the raising of the hand to the hair." 55

Readers were presented with a litany of dramatic characters to identify, to emulate or to avoid becoming, such as the smoker whose habit became a vice, for she was "Apt to be too thin, haggard, hard-lipped, somehow desiccated." This was one of the very few references to nicotine addiction. There also were two stereotypes of the New Woman: the "masculine woman smoker: brusque, direct, studiously casual," and "the professor's wife who has just taken it up [that] week as her first revolutionary step towards sophistication....She will smoke once, perhaps [to be] emancipated." The lesbian New Woman was a fairly recognizable figure in American popular culture by the 1930s, and this characterization is not an unsympathetic one..$^{56}$ The Professor's Wife would have been even better known to a reading public, since she harkened back to Dorothy Richardson's Pilgrimage, in which the author recalled the first act of smoking as a signifier of her attainment of the New Woman role in the 1890s. ${ }^{57}$ The "eccentrics and exotics in smoking: the obese modern poetess with a black cigar clamped in her critical mouth; the old French countess wedded to her stogie; the Ozark crone puffing on her pipe; the languid, sinuous, ruinous Roumanian holding in her experienced lips a long, thin, perfumed cigarette from Russia." Ozark crones, like other country women smoking and rocking on creaking porches, were stereotypes of films dating back to silent pictures, vaudeville routines, and anti-tobacco tracts. ${ }^{58}$ The obese cigar-smoking poetess would have been recognized by a literate audience as Amy Lowell, who died in 1925, but who had several works and a major biography published in the intervening years. ${ }^{59}$ The most famous image here, however, was the decadent Romanian aristocrat. The year 1934 saw the release of "The Scarlet Empress," with Marlene Dietrich as Catherine the Great, as well as the publication of The Story of My Life by Queen Marie of Romania, granddaughter of Queen Victoria, participant in the 1919 Paris Peace Conference, and Society Woman writ large for 20 years. ${ }^{60}$ Her relation, Marie [Pavlovna], Grand Duchess of Russia, had previously published Education of a Princess in 1930, demonstrating the public fascination with fallen Romanoff (and European) royalty. ${ }^{61}$ The non-reading public took their images of the Russian femme fatale from models dating back to the silent film sirens Theda Bara ${ }^{62}$ and Pola Negri. ${ }^{63}$ "The Nicotined Lady," published in a decade of increased graphic and textual references to smoking, prescribed smoking as an essential component of the Vogue reader's attainment of an opulent fantasy self.

This fantasy self did, however, require some work. Refinement was an essential feature of respectable femininity and feminine beauty; it "required attention to the finer details of appearance and depended on 
careful maintenance and control/containment of the female body." 64 The practice of smoking could easily undermine refinement and, through this, respectability. Stained fingers and teeth, tobacco threads on the lips, uneven lipstick, all were evidence of a lack of feminine refinement. Acknowledging the importance of these details for the female smoker, Marlboro's tentative early adverts in US Vogue in the 1930s described how they were "Ivory tipped for lip insurance," reflecting concern for lipstick and lipstick stains. ${ }^{65}$ Marlboro soon expanded its not-subtle appeal to the sophisticated American woman: "Marlboro is swankiest of all smokes.... A clean smoke, clean to the lips, to the finger tips, to the garments!"66 In Britain as well, women smokers were expected to combine smoking and feminine refinement although in the pages of Vogue this was not made explicit in cigarette advertisements. ${ }^{67}$ The importance of the clean smoke was important to women particularly as heavy smoking was on the increase and encouraged by the tobacco industry. American women who smoked Spud were advised to "Smoke 'til the Midnight Spread," to "smoke more on lazy days" and reassured, "Second pack today? No Matter!"68 That not only female smoking, but also heavy smoking, was accepted reflected significant advancement in the naturalization of the habit since the twenties.

During the forties, the Vogue woman went to war, and sophisticated pleasure seeking was a difficult image to maintain (certainly balls in Parisian salons were out of the question). US Vogue attempted unsuccessfully to maintain the image of affluent lifestyles despite wartime shortages, with accounts of fancy USO parties for celebrities and men and women in uniform. The magazine was more comfortable, however, with novels like John P. Marquand's So Little Time, which recounted the wartime confusions among New York's "oppressed upper classes," who still made the rounds of glamorous parties of cocktails and cigarettes. ${ }^{69}$ Despite shortages, cigarette adverts continued to target the woman smoker in the context of her war work and her wartime pleasures. ${ }^{70}$ Marlboro, "America's Luxury Cigarette," made textual and visual links between smoking and affluent, glamorous femininity: "A hat to outdo all others. Ditto her cigarette... distinguished Marlboro"; "Very scant blouse. Very lush skirt. Very right! Very right too, her cigarette."71 The smiling host of a candlelit dinner party offered Chesterfield cigarettes to her guests because "You can't buy a better cigarette." ${ }^{2}$ Smoking clearly remained a fixture of sophisticated feminine pleasures.

The cigarette also remained an accessory of the social elite in British Vogue. But while Miss Penelope Ward sported a cigarette while modelling a satin gown, ${ }^{73}$ women smokers were as often portrayed in smart and serviceable clothes suggesting that they had largely relinquished the good life in order to "do their bit" for the duration of the hostilities (Figure 6). ${ }^{74}$ Jostling for space alongside adverts for "utility corsetry" 75 and 
for masculine-style women's coats, designed to "withstand hard weather" and to provide "hard wear," 76 cigarette adverts abandoned their appeal to glamour and opted instead for displaying the packet. These cigarette packets were often masculine in design (for example, Player's Navy Cut and Three Castles) and did not explicitly target women or embrace them as smokers. ${ }^{77}$ The absence of women smokers in cigarette advertisements was, however, consistent with advertising in other aspects of the British print media; the middle-class Woman magazine, for example, which had carried three or more cigarette adverts per issue in the late 1930s carried no cigarette adverts from 1940 through to $1944 .^{78}$ The needs of the woman smoker were not as important as those of the male smoker even though both Service men and women were issued with cigarette rations and, by 1949, 41\% of British women aged 16 and over were smokers. ${ }^{79}$

Figure 6

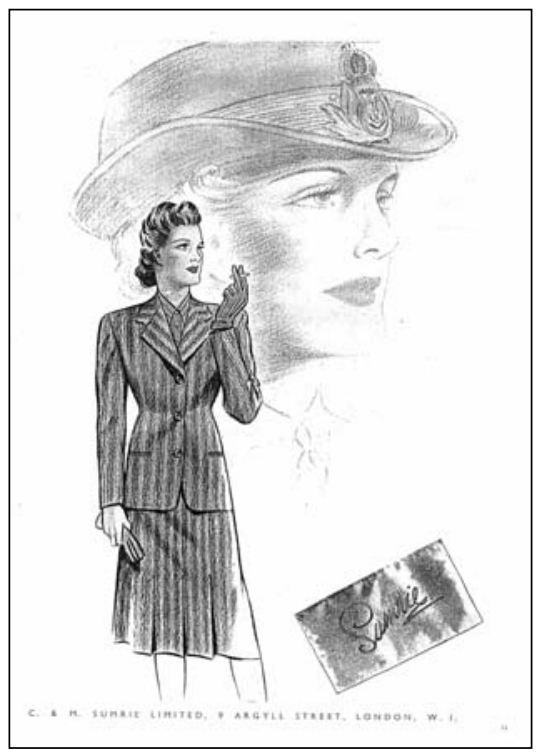

"Sumrie" advert, British Vogue (February 1944), p. 73.

In the decades after the war, smoking remained a prominent feature of sophisticated lifestyles. However in 1950s America, the Cold War values of domesticity and submissiveness displaced hedonism and, by 1954, Society highlife was thoroughly domesticated. Many of the articles and fashion displays took place in elegant dens and cottages. An article entitled, "The Good life, Inc." about an architect, portrayed a den party with many smokers, doubtless using the variety of cigarette lighters advertised on other pages. Following a trend apparent from the thirties, moth- 
erhood was seen as incompatible with the hedonistic lifestyle celebrated in Vogue, although annual listings of private schools and summer camps did give a nod to the reality of progeny.

Figure 7

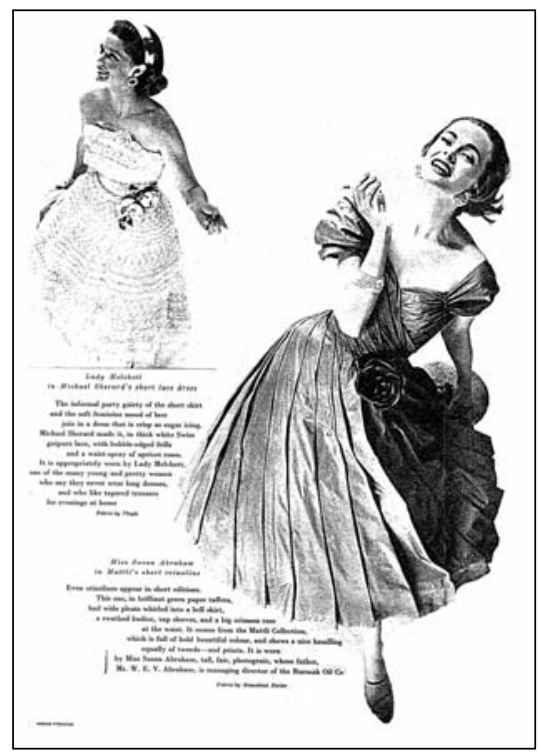

British Vogue (March 1954), p. 163.

In the fifties, British Vogue was again responsive to the straitened circumstances of some of its readers as illustrated by the depiction of a young woman smoker photographed in skirt, blouse and cardigan in a feature entitled "more taste than money." 80 Affluent and sophisticated leisure nevertheless retained their visual dominance and adverts for cruises around the West Indies and the South African Cape ("reduced first class fares" offered) revealed a globetrotting Vogue reader. ${ }^{81}$ In acknowledgment of this, adverts for State Express 555 boasted they were "the best cigarettes in the world." 82 Society belles modelled the latest fashions with cigarettes in hand (Figure 7). ${ }^{83}$ Women smokers reemerged in cigarette adverts to persuade readers of the place of smoking in the good life, but unlike their prewar counterparts, they were increasingly located in domestic and matrimonial settings. ${ }^{84}$ The domestic theme also was elaborated in a series of adverts for Ronson lighters, each of which depicted a woman smoker with her adoring new husband amid a selection of domestic objects (Figure 8). Each advert represented a different and very modern lifestyle within which the Ronson lighter was indispensable; "Today's most fashionable wedding present," ideal for "cocktail and dinner parties." 85 
Figure 8

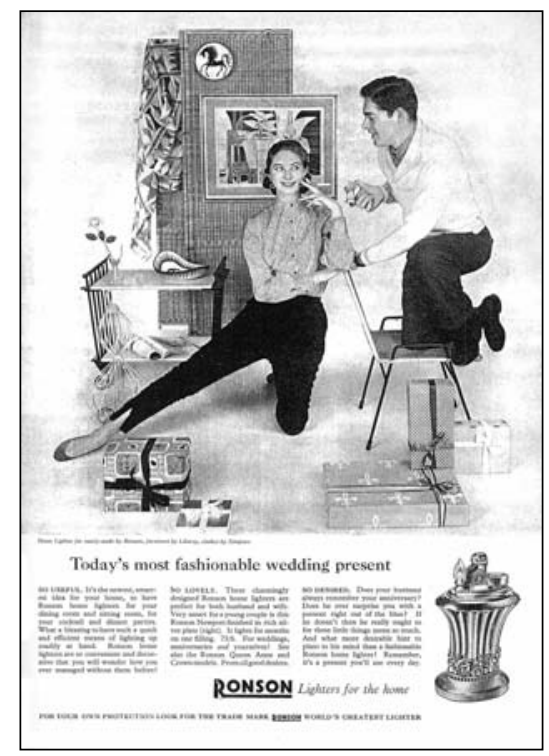

"Ronson," advert, British Vogue (April 1954), p. 217.

Parties and international travel were the dominant features of feminine lifestyles depicted in British Vogue of the sixties. In 1964, adverts for hotels and travel outnumbered those for fashion for the first time in Vogue's history, and alcohol adverts outnumbered those for cigarettes. While the Vogue woman was increasingly seen with a glass in hand, the cigarette was only occasionally glimpsed in fashion features, ${ }^{86}$ an advert for cruises on the Cunard and one for Cointreau ${ }^{87}$ Growing publicity about the health risks of smoking probably lessened the glamour of the cigarette for fashion photographers and advertisers of non-tobacco products. ${ }^{88}$ Gendered advertising practices also contributed to the low profile of the woman smoker as women were increasingly displaced in cigarette adverts by men or symbolic objects. These practices may have been because advertisers assumed that smoking already was established as a feminine practice (in 1965, 46\% of 16-24 year olds were smokers ${ }^{89}$ ) and that there was, therefore, less need to visibly link cigarettes with women. Cigarette manufacturers may also have masculinized advertisements in a bid to stem the decline in the proportion of men smoking cigarettes which had occurred following the 1960s' health campaigns which pointed to the dangers for men of smoking (at this time women were widely perceived to not be at risk)..$^{90}$ As a result, in 1964 there were more cigarette adverts in British Vogue that portrayed men than women smokers. ${ }^{91}$ This was in marked contrast to interwar cigarette advertising; 
three-quarters of cigarette adverts in the 1930s specifically featured women as actual or potential smokers. ${ }^{92}$ The lower profile of the female smoker in Vogue was, whether intentional or not, consistent with a reduction in the proportion of smokers among Britain's feminine elite. ${ }^{93}$

Figure 9

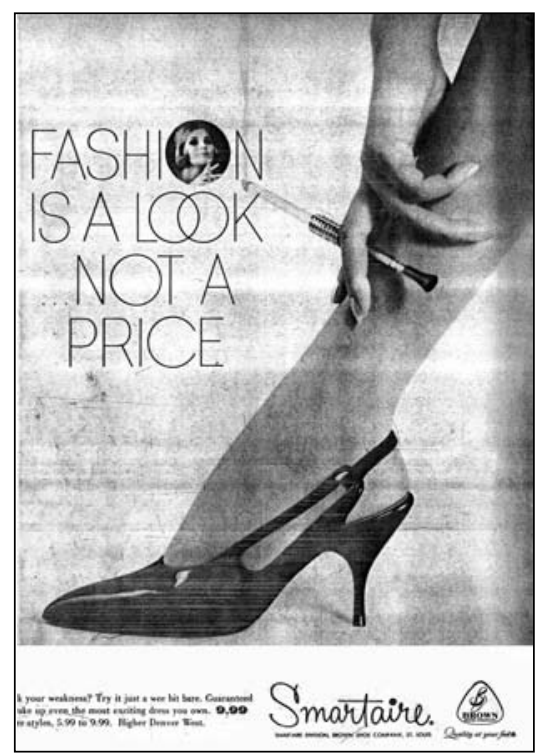

"Smartaire" advert, US Vogue 143 (15 January 1964), p. 34.

Compared to the flatness of the fifties, the sixties swung in US Vogue. Society figures were back at cocktail parties with cigarettes and champagne glasses in scenes reminiscent of the Jazz Age, although home parties also were celebrated. The Kennedy years were reflected in accounts of soirees in Washington, where the powerful and rich enjoyed liquor, cigarettes and jewels. That smoking remained part of this sophistication was spelled out in the ad for Smartaire shoes, captioned "Fashion is a look not a price" displaying shoes with a cigarette in holder (Figure 9). ${ }^{94}$ Travel again was presented as a sophisticated ideal-both domestic forays to Florida resorts 95 and more exotic Caribbean cruises (for the Career Woman to meet the Ideal Man and abandon her independence $)^{96}$ and European capitals. A fashion spread selling Italian clothing, liquor, shoes and "nobility" promoted European glamour with a photograph of Princess Laudomia Hercolani reclining with cigarette. ${ }^{77}$ Unlike spreads in the interwar period, however, this advert did not celebrate European glamour above the American affluent lifestyle. 
The sophisticated glamour of the Vogue lifestyle required "The Look," and "The Look" necessitated an ever-slimmer physique. In 1946, George Orwell described the Vogue model in terms that recalled the images of earlier decades: "One striking thing, when one looks at these pictures, is the overbred, exhausted, even decadent style of beauty that now seems to be striven after. Nearly all of these women are immensely elongated. A thin-boned, ancient-Egyptian type of face seems to predominate: narrow hips are general, and slender, non-prehensile hands like those of a lizard are quite universal." 98 From the twenties, there was an overt connection made between smoking and slimming in US Vogue, but this was displayed in the fashion spreads and text, not in tobacco advertisements. There were corollary adverts for slimming products and corsets, so that the journal taken in its entirety stated that fashions $=$ slimming $=$ corsets = smoking. ${ }^{99}$ An addition to the fashion spread, "Dainty Lingerie from New York Shops" was the description of a custom-made girdle, emphasizing that the desired physique of the twenties was not naturally attainable by many readers (Figure 10). ${ }^{100}$ In "Paris holds the mirror up to fashion," the text read: "The modes of 1924 seem determined to keep us to a rigorous course of diet and exercise, if we mean to make any pretension of wearing them properly....There is no peace for the 'fleshy,'" and accompanied a pictorial of four models, one of whom smoked. ${ }^{101}$ By 1934, dieting was portrayed not only as necessary, but also as chic. "Entertaining Gossip," a column describing champagne parties of the New York elite, stated, "everyone is following some diet or other. It's even penetrating into the hotels, for the Mayfair has taken up Doctor Hay in a big way." 102 Photo-essays portrayed socialites playing racquet sports, running and engaging in other forms of exercise, ${ }^{103}$ while an increasing number of corset advertisements targeted the non-athletic. 104 A very evocative image of a woman's multifaceted attempts to control the body is found in a Foundettes by Munsingwear in 1934, where a woman in full body corset holds a cigarette (Figure 11). ${ }^{105}$

The British woman smoker of the interwar years was also slender. This equation of beauty and thinness in the smoker was consistent with new ideals of feminine beauty that gained ground in the 1920s, displacing the Edwardian ideal of the mature and voluptuous figure. ${ }^{106}$ As Nurse Challoner explained in an advert for her "special pills": "A good figure is the Secret of Youth and Beauty. Why be Fat and Old-looking...?"107 The young model that appeared in 1918 in one of the first fashion adverts to feature a woman smoker had a round face and a soft neck and shoulders but, although the outline of her body was hidden, she was also slender and girl-like. ${ }^{108}$ By 1920, fashion features and cigarette adverts portrayed a more angular, trim and slender smoker. Ideal 
Figure 10

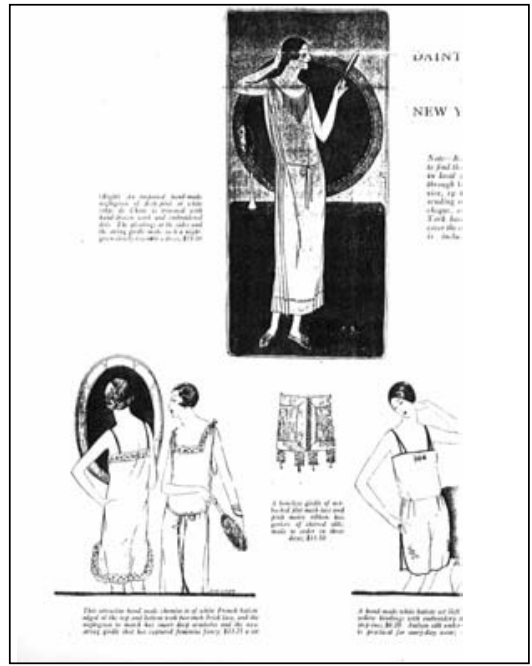

“Dainty Lingerie from New York Shops," US Vogue (15 January 1924), p. 68.

Figure 11

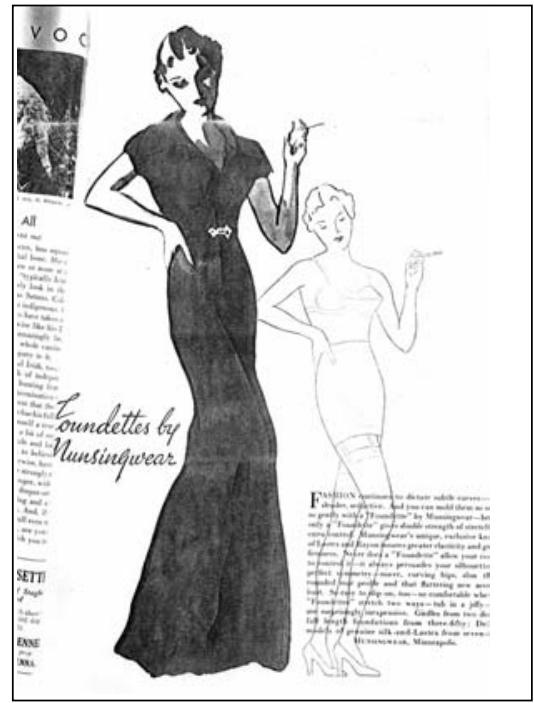

"Foundettes by Munsingwear" advert, US Vogue (1 March 1935), p. $16 \mathrm{~S}$.

body shapes changed over the following decades in line with fashion ${ }^{109}$ but the ideal of the thin woman, with or without curves, remained to the fore. Smokers and non-smokers alike were portrayed in Vogue fashion 
features as slim and attractive; similarly in adverts for all sorts of products, including cigarettes, female models were thin. The fuller figure that was fashionable in Edwardian Britain was, after 1920, a sign of the loss of youth; even fashionable older women were, after 1930, invariably slender and trim.

The location of smoking in a nexus of messages about slimness, which was such a feature of US Vogue, also was apparent in its British counterpart. Cigarette adverts featured alongside adverts for slimming aids such as one for Natex reducing food, which promised "slim beauty in 3 weeks." 110 Corset advertising similarly highlighted the fashionable slim profile and neatly equated this with the glamour of the cigarette. One advert for corsets featured a woman smoking and promised readers "That streamline figure is yours in a Berlei" (Figure 12). 111 The full-page sketch reveals a long slender model in a Berlei figure foundation and an evening dress sketched over the top. The woman wears make-up and jewellery and she holds a cigarette in her outstretched arm. The cigarette contributes nothing aesthetically to the image but it does convey the impression of an elegant and sophisticated woman, a woman that we can see is supported by Berlei foundation. The cigarette is part of the elegant feminine look that the corset produces. Cigarettes are not presented explicitly as an aid to the control of a woman's figure. However the association of smoking with being slim, as well as attractive, happy and comfortable, is consolidated through the recurrent juxtaposition of messages in the pages of British Vogue.

Figure 12

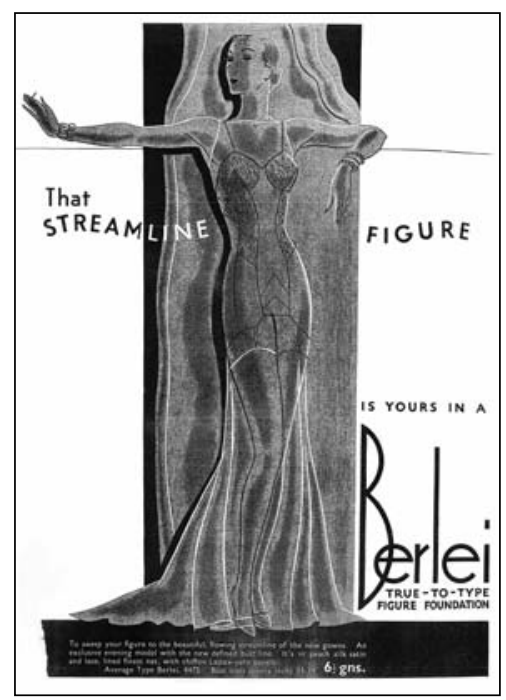

"Berlei" advert, British Vogue (3 October 1934), p. 44. 
The explicit association of smoking and weight control does not feature in cigarette adverts in British or US Vogue in the interwar years. However, in America in the late 1920s and early 1930s there was a very successful high profile advertising campaign for Lucky Strike cigarettes which explicitly linked smoking to weight control. ${ }^{112}$ This advertising gimmick was reproduced in Britain in adverts for Kensitas cigarettes which were targeted at men and especially at women in the national press. ${ }^{113}$ Although Lucky Strike and Kensitas cigarettes were not advertised in Vogue, it is likely that, on both sides of the Atlantic, intertextual associations informed women's readings of interwar Vogue and consolidated further the association of smoking and slimness.

During the forties, wartime realities such as female employment and rationing did not derail preoccupation with the thin figure. In the US, the article "Plan Your Weight" was juxtaposed with a picture of a ballet dancer, the slimmest of female ideal types. ${ }^{114} \mathrm{New}$ diet products such as Ayds Reducing Candy ("Once an Overweight-now looks like a Model" or the even more memorable, "Too dumpy for dirndls?") joined the traditional corset adverts, although the focus shifted to a dynamic female lifestyle. ${ }^{115}$ The women in American Marlboro ads became progressively thinner, ${ }^{116}$ (Figure 13) while the Saks fashion spread of a woman with cigarette displayed "The heavenly body line of a slim formal gown."117 By 1954, the connection between the idealized thin figure and smoking was confirmed in US Vogue. Even Hansen evening gloves, pictured worn by a smoking woman, were described as having "Fashion's new narrowness in the fitted glove nipped to give your wrist a waistline."118 An increasingly slim silhouette was apparent in fashion spreads with smoking models in tight clothing. Associated products, such as Sucaryl sugar substitute, were recommended de rigueur for every woman's pillbox. By the 1960s, smoking was prescribed overtly as a diet aid. The advert for Metrecal, a calorie-reduced meal replacement, asked, "Have you started to gain weight since you gave up smoking?" and juxtaposed a cigarette being put out in an ashtray with a nude slim woman. ${ }^{119}$

Preoccupation with weight was not as pronounced in British Vogue as in its American counterpart although slimness remained the feminine ideal throughout the forties and into the postwar decades. Figure hugging fashions of the fifties, most notably "The Chanel Look" were paraded in front of British Vogue readers by women who smoked:120 "We take from France the skilled sophistication of our after-five dresses: slim, with a dramatic note or two."121 Fashion shots of models with tightly belted waists holding elegant cigarette holders or drawing seductively on a cigarette accentuated the slim line associations of smoking as did some tobacco promotions. ${ }^{122}$ Prefiguring the sales pitch of the phenomenally successful slim "female cigarettes" of the late 1960s which linked style of cigarette with body shape, ${ }^{123}$ an advert for Toledo cigars stressed that: 
Figure 13

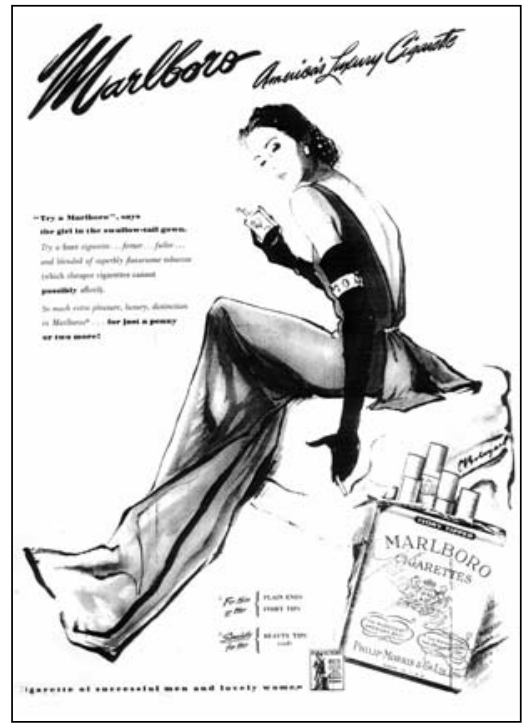

“Marlboro" advert, US Vogue (15 September 1944), p. 195.

"They're long, slender, golden and mild—so smooth, in every way, that they belong in a girl's smoking wardrobe." 124 As the reference to "girls" indicates, the Toledo smoker was envisaged to be a young woman. This is not surprising as youth and slimness went hand-in-hand in sixties Britain, but the youthful profile of the woman smoker had a longer history.

\section{THE “LOOK” OF THE FEMININE SMOKER—TO BE YOUNG}

From the outset, British Vogue featured women smokers as youthful and, frequently, as single. Small adverts for perfumed ladies cigarettes, which featured regularly until the mid-1920s, sometimes relied on the testimony of married, perhaps older, women. ${ }^{125}$ However, illustrations in these adverts invariably portrayed a young woman smoker. Adverts for mass-produced cigarettes frequently made an explicit link between smoking and young, single womanhood as in a series of De Reszke adverts in 1919 and 1920, which featured Miss Fay Compton and Miss Kyrle Bellew (Figure 14). ${ }^{126}$ Supporting testimonies from single women reinforced the youthful association although these women may not, in actuality, have been young. Youthful associations, however, were confirmed by the images of the women smokers. In a rare article on smoking, "Fair comment on men, maids and manners," the practice is clearly linked to the young, single and fashionable: 
Figure 14

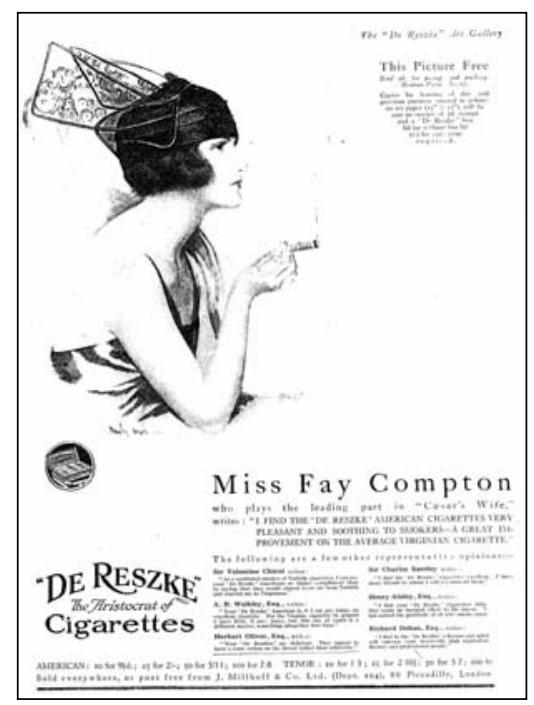

“De Reszke" advert, British Vogue (early May 1919), inside front cover. [136Brit.tif]

We are always being told that cigarettes, especially those made of American tobacco, have done a grave injury to English maidenhood and English manners. The very slang that they engendered destroys romance, and what was once called conversation. A siren with a "stinker" between her lips does not inspire an epigram or a lyric. We have been passing through the awkward age when instead of conversing we "S.O.S.'ed" in a monosyllabic slang. It might be called the "Abbreviated Period" — short skirts, short shrift, short credit and short names. But there are signs that reaction is at hand. ${ }^{127}$

Cigarette advertising in 1930s Britain continued to align smoking with visibly young, and often single, women in their late teens and twenties. ${ }^{128}$ Adverts for Player's Bachelors which targeted the "Bachelor Girl" in Vogue, and other women's magazines, exemplified this trend from the late twenties through to the Second World War. ${ }^{129}$

In fashion promotions, and from the 1930s in cigarette advertisements, the woman smoker was not necessarily in her early twenties or unmarried. ${ }^{130}$ However, it was often difficult to determine a woman's age in the pages of Vogue because the visual distinction between a young woman in her early twenties and a woman in her thirties with youthful good looks was blurred. The demise of the flapper look, and the advent of more sophisticated and elegant feminine fashions from the late 1920s, made it difficult to identify a young woman by dress alone. A further complication was that good looks were essentially youthful ones. Whereas prior to the Great War, the voluptuous woman in her thirties represented the height of feminine beauty, the ideal that gained ascendancy by 1920 was: "not so much boyish as youthful."131 Anti-ageing 
creams were advertised to "Ladies in Society, Actresses and Artists to whom a youthful appearance is essential."132 Women smokers always were portrayed as attractive and, because youth was key to feminine attractiveness, they were portrayed as youthful. This remained the case in the pages of British Vogue through to the sixties.

Youth was not, however, always key in cigarette adverts in interwar images of the American woman smoker. The frequent appearance of mature women in US Vogue demonstrated both a respect for age lingering from the 19th century, as well as perhaps recognition that much of the target elite market for the magazine and its products would be older women in possession of their own disposable wealth. Several testimonial adverts for cigarettes as well as automobiles featured photographs of older women, surrounded by opulent furnishings, jewels, and chauffeurs. Camels, for instance, trotted out dowagers named Coolidge, Carnegie, Lowell, and Fish to praise their choices of cigarettes. ${ }^{133}$ The reverse of this, and harbinger of the trend to last for the rest of the 20th century (and beyond) were adverts for corsets to control or "mould" the mature figure;" to avoid envying "the slim young thing? It is smart to be 'past thirty," but above all, to deal with "the tragedy of a young face and an old figure." 134 Yet the dowager could be substituted by the sexually experienced-even voracious - image of the older woman, as was evident in Vogue fiction: "There is port. Chill tea. Smoke. Thickened voices....The woman next to him, leaning toward him, asks him if he has a 'briquet,' and, as he lights her cigarette, he smells her scent and sees her wrinkled throat and glistening eyes." 135

By the forties, the mature woman smoker, as well as her non-smoking sister, rarely appeared in US Vogue. The vibrancy, physical prowess and optimism of youth were the values required for the global adventure. A few adverts, such as those for the department store Bonwit Teller, ${ }^{136}$ displayed fashionable mature women with cigarettes (Figure 15), while features like "Care of the Figure" offered quick diets and exercises for mature hips. ${ }^{137}$ Sophisticated youth prevailed, however, in cigarette adverts, no doubt assisted by the equation of youth with the American ideal of the slender feminine body. The shift away from testimonial advertising accompanied by photographs of good customers, and towards elegant illustrations and photographs of professional models, probably assisted the visual shift in the representation of the American woman smoker. The US Vogue of the fifties afforded some respect to the (affluent) mature woman with the introduction of "Mrs Exeter," a fictional character in her fifties or sixties who modelled fashions in opulent surroundings while holding a cigarette. ${ }^{138}$ An article on designer Coco Chanel, portrayed with cigarette, celebrated an older, independent woman, yet significantly the picture was taken in 1937 and was presented as an historical artefact. ${ }^{139}$ By the sixties, reference to the older woman was rare. 
Figure 15

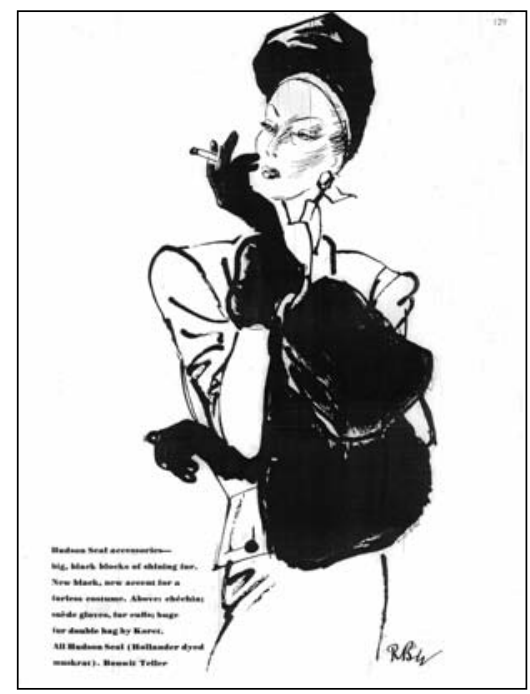

“Bonwit Teller" advert, US Vogue (1 November 1944), p. 129.

\section{THE CONFIDENT WOMAN SMOKER IN VOGUE}

Confidence was a trademark of the woman smoker in adverts and fashion spreads in the pages of Vogue. ${ }^{140}$ In one fashion spread of the 1920s, the smoking model is set apart from the other two, more assertive and in contrasting garb (Figure 16). ${ }^{141}$ Confidence and power remained prominent in representations of the American working woman of the thirties (Figure 17).142 One expensive fashion lay-out of 1935 presented an interesting contradiction of a puffed-sleeved dress coyly labelled the "Little Women Dress," and the confidently posed, modern-looking smoker who modelled it. A more common and consistent product was the man-tailored suit-uniform of the urban career-woman complete with cigarette, à la Rosalind Russell in "His Girl Friday" or Kate Hepburn in "Woman of the Year." 143 Paying some heed to the Depression year of 1934, the photo spread, "Vogue's Smart Economies" illustrated three working women in suits, all of whom were lighting cigarettes. ${ }^{144}$ In the patterns feature, "Couturier Designs for Practical Dressmaking," the centre model of three faced frontward, holding a cigarette, and wearing the dress with the cleanest, least frilly lines. ${ }^{145}$

In Britain too, confidence, capability, and independence were trademarks of the woman smoker. In contrast to the US, however, women's smoking in British Vogue was related overtly to emancipation and modernity through the medium of cigarette advertising. Full-page colour adverts for the mass-produced De Reszke brand of cigarettes introduced a dynamic modern woman smoker (Figure 2). The De Reszke smoker 
Figure 16

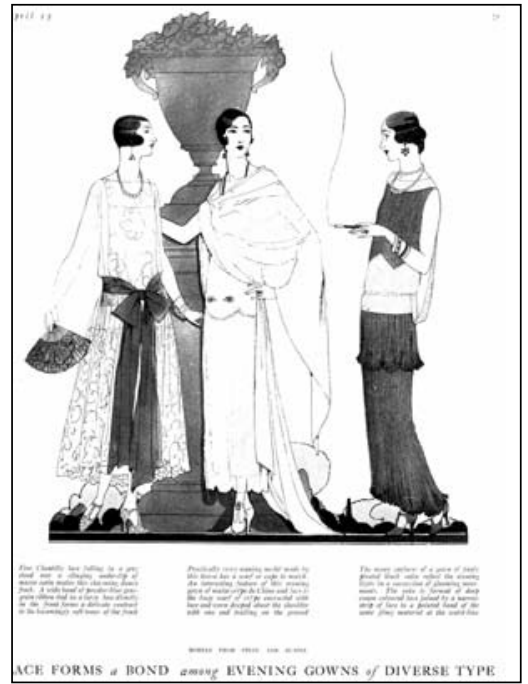

US Vogue (15 April 1924), p. 75.

Figure 17

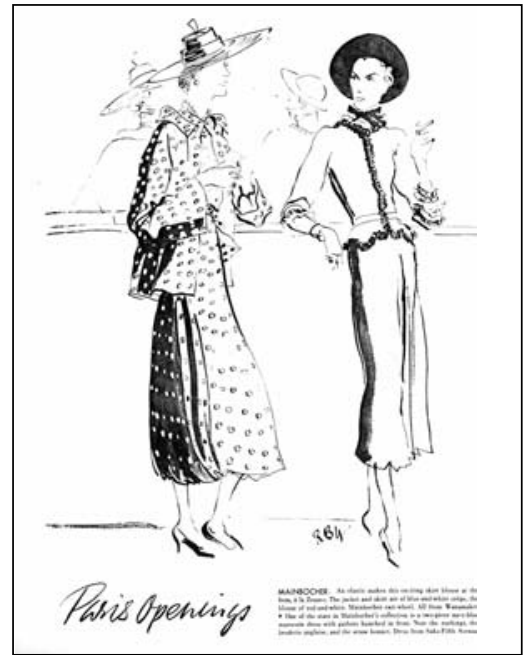

“Paris Openings,” US Vogue (1 March 1935), p. 46.

was confident in her right to use public space, to associate with men without a chaperone, to be physical and to steer her own course in life. "Sybil" accompanied a young man to Lords, "Daphne" offered a man a 
cigarette at the Royal Academy and, on a summer's day, "Evadne" entertained a young man by taking him punting down the Thames at Henley. ${ }^{146}$ Independence and confidence also were common themes in Player's adverts of the 1930s which, for example, featured a woman smoking travelling alone on a train. ${ }^{147}$ Another Player's advert depicted a woman smoker seated in quiet confidence, possibly waiting for someone in a hotel lobby. Although the woman's gaze suggested that she was looking towards someone, the explicit and sole focus on the woman clearly indicated her status as an independent woman. ${ }^{148}$ Player's also employed the theme of the independent woman in its adverts for Bachelor cigarettes. The explicit promotion to women of a brand called "bachelor" suggested that women were now part of the modern male world on equal terms with men.

One of the key areas in which modernity and the confidence of the woman smoker were conveyed was in her relations with men. Heterosexual attractiveness and self-confidence were explicit characteristics of the women who smoked De Reszke cigarettes. Even when "Evadne's" young man offered cigarettes to a woman in another punt, Evadne held her head high, assured of her superiority as it was she, rather than her male companion, who was at the helm with a De Reszke cigarette: "Serenely conscious of admiring eyes, Evadne fears no rival belle....No green-eye monster haunts Love's Paradise, When a 'De Reszke' weaves its magic spell!"149 In many interwar cigarette adverts targeted at Vogue readers, the heterosexual context was hinted at but it was not usually defining, and women were more likely to be depicted alone than in male company. Though cigarette adverts rarely featured women in the forties, the twin themes of independence and confidence remained to the fore in representations of women smokers in fashion promotions. In British Vogue, the 1940s woman smoker needed no male prop; she was attractive, confident, competent, and independent. 150

In US Vogue, the image of the confident smoker lent itself easily to wartime liberation as the magazine tentatively delved into news journalism with accounts of pioneer physician Elizabeth Blackwell and the fight of female physicians to serve overseas. ${ }^{151}$ As has been written elsewhere, both World Wars were superb opportunities for tobacco companies to consolidate their hold over millions of smokers in the 20th century, through their "donations" of cigarette rations. ${ }^{152}$ Camels exploited their patriotic endeavours through adverts describing the man home on furlough, enjoying the "favourite cigarette with the armed forces." Camels replaced dowager testimonials with those of "Women in the War," including cryptographers, steel workers, and adventurous war correspondents like Pegge Parker "ace war reporter," parachuting, riding tanks and smoking Camels. ${ }^{153}$ The "New Woman of the War" was an uncomfortable fit for Vogue and its advertisers, as indeed it was for the 
larger society. The clothing sold was "man-like gabardines," and the "man-tailored" Miss Cricketeer suit, which made "Even Professors perk up."154 The Marlboro woman was still a glamorous smoker, yet a man in uniform lit her cigarette. ${ }^{155}$ Some advertisers had difficulty incorporating contradictory female ideals in a period of rapid social change. In a dizzying mix of traditional and contemporary values, Pond's testimonial of a society girl cum plane riveter trumpeted "She's Engaged!" while "adorably in earnest about her war job." 156 Cheney fabrics also displayed similarly mixed images, such as a woman lounging with a cigarette ("during the day you might find her working in a vital war industry") while the Marlboro woman of 1944 still carried flowers. ${ }^{157}$ Smokers were still common in the fashion spreads, although the women were active in sports, like horseback riding. ${ }^{158}$ Forty-eight-hour leave weddings were promised for Marlboro smokers (with beauty tips-red—for her) ${ }^{159}$ and wearers of Gossard corsets (complete with a future dream-house purchased with War Bonds) (Figure 18). ${ }^{160}$

As women were more public in the workplace during World War II, their bodies also were more publicly in the marketplace. One of the outcomes of this was the transformation of the US Vogue woman into a spectacle. A series of adverts for Helen of Hollywood corsets displayed cartoons consistent with those shown in soldiers' magazines: Several men at a bar, in various uniforms, leered at an unseen shadowy woman, "Now, Gentlemen, there is a Figure!" while two of the men, relaxing at side court, admired Carol's "marvellous form" as she played tennis. ${ }^{161}$ Woman as economic competitor was no longer woman on the pedestal, and generalized acceptance of the female body as object of display was now apparent in the pages of US Vogue. Pin-up style representations of seductive glamorous women smokers were even featured in several wartime adverts for Marlboro cigarettes. ${ }^{162}$ The confidence of the wartime woman smoker was commonly presented in US Vogue as explicitly heterosexual but by the fifties, and on both sides of the Atlantic, the woman smoker was represented as increasingly confined within heterosexual relations.

By the 1950s, a new image of female powerlessness and infantilisation was being presented in the pages of US Vogue, in sharp contrast to the dynamic images of the forties. ${ }^{163}$ Slimming and exercise were reconfigured for the "Lazy Woman," who could use a motorized chaise longue, 164 and a two-page spread, "More Taste than Calories" (a guide to low-calorie packaged foods), displayed a series of shots of a man spoon-feeding a woman. ${ }^{165}$ The epitome of this imagery was an advert for Munsingwear Nylons, entitled Pink Canary, where a woman is literally portrayed in a gilded cage (Figure 19). ${ }^{166}$ An advert for Humming Bird stockings displayed a man leering at a woman's legs, exemplifying the loss of power inherent in the cutting up of body parts for display. ${ }^{167}$ The relationship between domesticity, the loss of financial independence and 
Figure 18

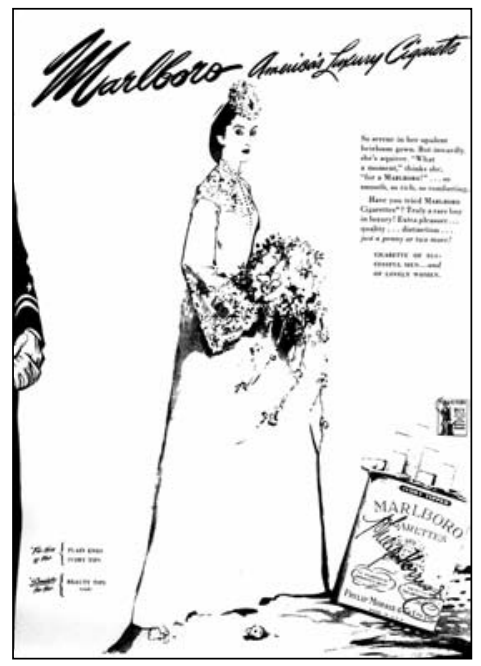

“Marlboro" advert, US Vogue (15 May 1944), p. 133.

Figure 19

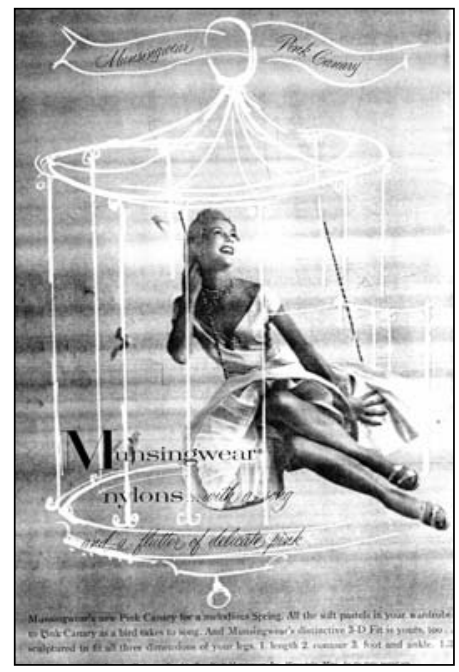

“Munsingwear Nylons” advert, US Vogue (1 April 1954), p. 14.

female powerlessness was recognized in the cloth advert, "How to keep him safe at home...Wear Jaunty Junior" (Figure 20). ${ }^{168}$ In this advert, the pun (being "safe at home") is represented by a male ballplayer in the background sliding to home. Yet the two female models in woollen suits in the foreground, one calling "out!" and the other nervously gesturing 
Figure 20

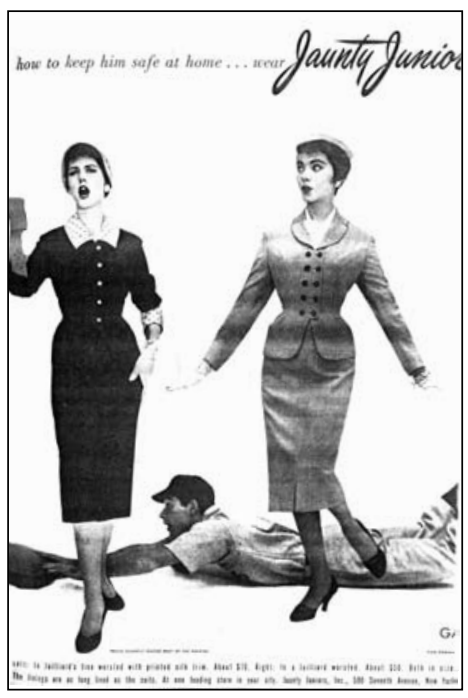

"Jaunty Junior" advert, US Vogue (1 February 1954), p. 67.

"safe," are virtually identical, emphasizing the easy replaceability of the housewife. Associated with female infantilization, and possibly the diminution of female disposable income for luxury products in 1950s America, was the increasingly frequent appearance of men and male consumer goods. Vogue in the 1950s carried many fashion adverts for business suits, cruisewear and sports wear, usually with men smoking cigarettes or pipes. ${ }^{169}$ Photo essays included shots of playwright William Inge and consummate chain-smoker and journalist, Edward R. Murrow. ${ }^{170}$ Many adverts displayed men in the foreground or seated, often smoking, with admiring women in servile positions below or standing behind them (Figure 21). ${ }^{171}$ Images of women smokers were less common in 1950s US Vogue. This was, in part, an outcome of the disappearance of cigarette adverts from women's journals as tobacco advertisers were lured by the publicity potential of television. ${ }^{172}$ Women smokers were, however, still portrayed as confident, sophisticated, and chic in fashion adverts of the fifties but, as in British Vogue, this was often a heavily (hetero)sexualized representation. ${ }^{173}$ While this representation acknowledged, even celebrated, female sexuality, this was potentially a framework for heterosexual female subordination as Betty Friedan and other early feminists began to discover. ${ }^{174}$

In contrast to the US, the foregrounding of the heterosexuality of the British woman smoker also occurred in tobacco advertising. Cigarette adverts, which became more common after the austerity of the forties, 
Figure 21

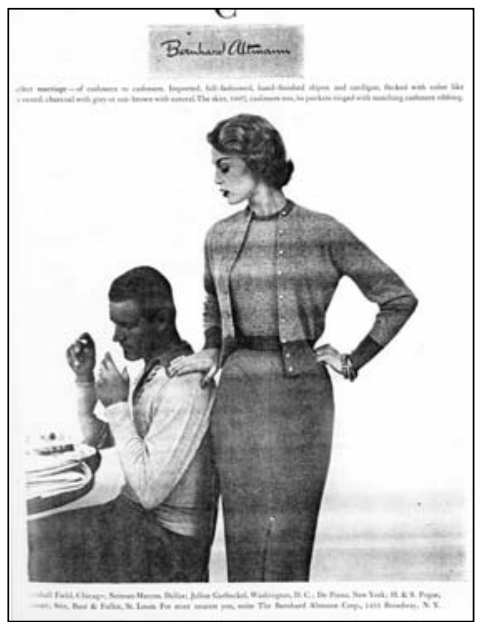

“Bernhard Altmann" advert, US Vogue (1 September 1954), p. 85.

located the woman smoker firmly within heterosexual relations as illustrated in the fifties by the "Two's Company" series of adverts for Player's cigarettes. Sometimes the romantic twosome in the Player's advert were featured in evening dress at a Society ball, but usually the couple's smoking experiences were domestic as in the advert where two trails of smoke rise from behind a sofa drawn up close to a roaring fire (Figure 22). ${ }^{175}$ Matrimony featured prominently in adverts for State Express 555 in which an elegant lady with cigarette in holder watched carefully as a wedding cake was cut by newlyweds. ${ }^{176}$ In adverts for lighters, the woman smoker also was most likely to be a newlywed. Confident and sophisticated women smokers continued to appear in fashion advertising but these were increasingly sexualized through photographic techniques that focused attention on seductive, often pouting (or inhaling) lips. ${ }^{177}$ Dreamy images of women smokers were also frequent in fifties Vogue. In an advert for Brenner fashions, a beautiful woman stands facing the camera with a cigarette in a holder. Smoking contributes to the elegant chic of this woman; it also accentuates her sexuality by highlighting her parted, ruby red lips (Figure 23). The woman's closed eyes and the faintest suggestion of a smile further enhance the sexual overtones, the implication is that she is lost in pleasant and romantic daydreams. ${ }^{178}$

By the sixties, and following in the footsteps of US Vogue, the woman smoker had a very low profile in British Vogue. Women smokers did not disappear completely from cigarette adverts (although they were rare in other features of the journal), but where women smokers were visible they were invariably accompanied by men. 
Figure 22

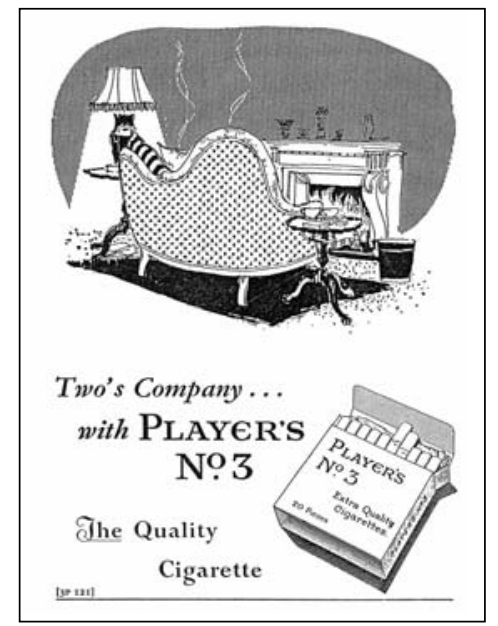

"Player's No. 3" advert, British Vogue (March 1954), p. 230.

Figure 23

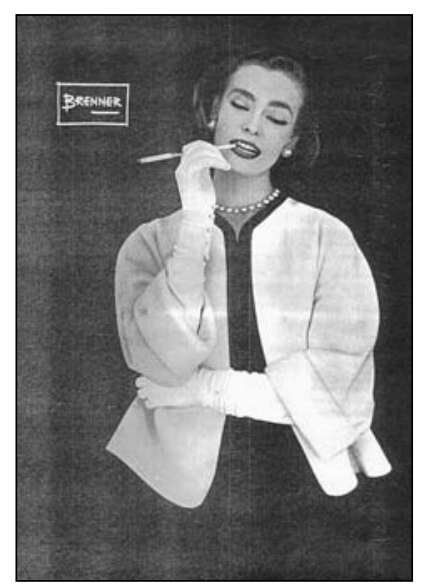

"Brenner" advert, British Vogue (March 1954), p. 46.

\section{CONCLUSION}

Vogue has thrived on both sides of the Atlantic from its launch early in the 20 th century to the present day. Amid lavish illustrations and photographs, this journal articulates an elite feminine smoking culture characterized by sophisticated pleasure seeking and the slimness and confidence of the woman smoker. This smoking culture has responded to social, economic, and political changes, as well as the initiatives and for- 
tunes of the tobacco industry. It was following the First World War that the equation of smoking and feminine elitism was established in the pages of Vogue, but the representation of this shifted in the years after the Second World War. Most notably, the sophisticated high life of the woman smoker became increasingly domesticated and her confidence increasingly confined within a restrictive heterosexual framework. The equation of smoking and slimness remained a fairly constant feature of elite smoking culture on both sides of the Atlantic although this was given increased graphic emphasis in the fifties and sixties especially in North America. Clearly there were strong parallels between representations of elite smoking cultures in the pages of British and US Vogue. Differences of national context should not, however, be glossed over. Commercial recognition of the American woman smoker proceeded extremely cautiously in the pages of US Vogue until the late twenties whereas British "ladies" were encouraged to purchase cigarettes from 1919. During the forties, however, British cigarette advertising suggested that smoking was not central to feminine life even if fashion features portrayed the cigarette as a necessary wartime prop. In contrast, American advertising and fashion features located the cigarette at the heart of the feminine war experience. In US Vogue the equation of smoking and slimness also was more explicitly and vociferously articulated than in her British counterpart. Whereas in British Vogue the equation of smoking and slimness always was aligned with the youthfulness of the woman smoker, it was not until the 1940s that US Vogue made this shift with full commitment.

\section{NOTES}

1 There is a growing literature on female smoking habits and representations. See, for instance, John C. Burnham, Bad Habits: Drinking, Smoking, Taking Drugs, Sexual Misbehavior, and Swearing in American History (N.Y.: New York University Press, 1993); Virginia L. Ernster, "Mixed Messages for Women: A Social History of Cigarette Smoking and Advertising," New York State Journal of Medicine (July 1985): 335-40; Lorraine Greaves, Smoke Screen: Women's Smoking and Social Control (Halifax: Fernwood Press, 1996); Matthew Hilton, Smoking in British Popular Culture 18002000: Perfect Pleasures (Manchester: Manchester University Press, 2000); Jarrett Rudy, The Freedom to Smoke: Tobacco Consumption and Identity (Montreal: McGill-Queen's University Press, 2005); Cassandra Tate, Cigarette Wars: The Triumph of the "Little White Slaver" (N.Y.: Oxford University Press, 1999); Penny Tinkler, "Refinement and Respectable Consumption: The Acceptable Face of Women's Smoking in Britain, 1918-1970," Gender E History 15, 2 (August 2003): 342-60; Tinkler, "Red Tips for Hot Lips: Advertising Cigarettes for Young Women in Britain, 1920-1970," Women's History Review 10, 2 (2001a): 249-72; Tinkler, Smoke Signals: Women, Smoking and Visual Culture in Britain (Oxford: Berg, 2006); and Cheryl Krasnick Warsh, "Smoke and Mirrors: Gender Representation in North American Tobacco and Alcohol Advertisements before 1950," Histoire sociale/Social History 31, 62 (November 1998): 183-222.

2 According to the 2001 U.S. Surgeon-General's Report on Women and Smoking, "This year alone, lung cancer will kill nearly 68,000 US women. That's one in every four 
cancer deaths among women, and about 27,000 more deaths than from breast cancer $(41,000)$. In 1999, approximately 165,000 women died prematurely from smokingrelated diseases, like cancer and heart disease. Women also face unique health effects from smoking such as problems related to pregnancy." National Center For Chronic Disease Prevention and Health Promotion, Tobacco Information and Prevention Source (TIPS), http://www.cdc.gov/tobacco/sgr/sgr_forwomen/ataglance.htm.

3 An earlier decline in American adult female smoking rates ended in the 1990s, while teenaged female rates rose sharply, particularly among women who had not completed high school. "Nearly all women who smoke started as teenagers-and $30 \%$ of high school senior girls are still current smokers." US Surgeon-General's Report, 2001. See also Elisabeth Rosenthal, "Across Europe, Women are Lighting Up," International Herald Tribune, 22 November 2004; and A. H. Crisp, C. Halek, P. Sedgewick, C. Stravraki, E. Williams, and I. Kiossis, "Smoking and the Pursuit of Thinness in Schoolgirls in London and Ottawa," Postgraduate Medical Journal 74, 874 (August 1998): 473-79. In most EU countries in 1999, girls had higher smoking rates than boys. Cited in Amanda Amos and Margaretha Haglund, "From Social Taboo to 'Torch of Freedom': The Marketing of Cigarettes to Women," Tobacco Control 9 (2000): 6.

4 Ian Tyrrell found a similar timidity on the part of tobacco advertisers in Australia to directly target women. See Tyrrell, "The Limits of Persuasion: Advertising, Gender and the Culture of Australian Smoking," Australian Historical Studies 31, 114 (April 2000): 27-49.

5 The study of gendered aspects of advertising is a lively field. See, for example, Diane Barthel, Putting on Appearances: Gender and Advertising (Philadelphia: Temple University Press, 1988); M. Susan Bland, "Henrietta the Homemaker and Rosie the Riveter: Images of Women in Advertising in Maclean's Magazine, 1939-50," Atlantis 8, 2 (1983): 61-86; Christopher Breward, The Hidden Consumer: Masculinities, Fashion and City Life 1860-1914 (Manchester: Manchester University Press, 1999); Jennifer Craik, The Face of Fashion: Cultural Studies in Fashion (London: Routledge, 1994); Ellen Gruber Garvey, The Adman in the Parlour: Magazines and the Gendering of Consumer Culture, 1880s to 1910s (N.Y.: Oxford University Press, 1996); Daniel Delis Hill, Advertising to the American Woman 1900-1999 (Columbus: Ohio State University Press, 2002); Roger Horowitz and Arwen Mohun, eds., His and Hers: Gender, Consumption and Technology (Charlottesville, University Press of Virginia, 1998); Jean Kilbourne, Can't Buy My Love: How Advertising Changes the Way We Think and Feel (N.Y.: Touchstone, 1999); Lori Anne Loeb, Consuming Angels: Advertising and Victorian Women (N.Y.: Oxford, 1994); Ellen McCracken, Decoding Women's Magazines: From Mademoiselle to Ms. (N.Y.: St. Martin's Press, 1993); Trevor Millum, Images of Woman: Advertising in Women's Magazines (London: Chatto and Windus, 1975); Carol Moog, Are They Selling Her Lips? Advertising and Identity (N.Y.: William Morrow, 1990); Mica Nava et al., eds., Buy This Book: Studies in Advertising and Consumption (London: Routledge, 1997); Roger Rosenblatt, ed., Consuming Desires: Consumption, Culture and the Pursuit of Happiness (Washington, D.C.: Island Press, 1999); Philip Scranton, ed., Beauty and Business: Commerce, Gender and Culture in Modern America (N.Y.: Routledge, 2001); Mary Vipond, "The Image of Women in Mass Circulation Magazines in the 1920s," in S. M. Trofimenkoff and Alison Prentice, eds., The Neglected Majority: Essays in Canadian Women's History, (Toronto: McClelland \& Stewart, 1979) p. 116-24; Nancy A. Walker, Shaping Our Mothers' World: American Women's Magazines (Jackson: University Press of Mississippi, 2000); Nancy A. Walker, ed. Women's Magazines 1940-1960: Gender Roles and the Popular Press (Boston: Bedford, 1998); Susan Ware, American Women in the 1930s: Holding Their Own (Boston: Twayne, 1982); and Cynthia L. White, Women's Magazines 1693-1968 (London: Michael Joseph, 1970).

6 We have performed a content analysis of sample years of Vogue (1924, 1934, 1944, 1954 and 1964), noting each textual or graphic citation of tobacco or smoking in advertisements, articles or fashion spreads. We also selected one issue per sample 
year and listed every item from cover to cover, noting size, use of colour and placement to determine the relative importance and prevalence of smoking references.

7 In 1924 women's smoking constituted only $5 \%$ of national tobacco consumption in the US and 1.9\% in Britain according to Jordan Goodman, Tobacco in History: The Cultures of Dependence (London: Routledge, 1994), p. 136. By the late 1940s, however, roughly one-third of British and US women smoked cigarettes. Early statistics for Canadian women's smoking rates are unavailable. However, by $1966,32 \%$ of Canadian women smoked, with consumption for women peaking at $40 \%$ in 1974 . Male smoking rates in Canada, by contrast, peaked in 1960 at $62 \%$. On Britain see Nicholas Wald, et al., UK Smoking Statistics (Oxford: Oxford University Press, 1988), Table 4.1.2. On the US, see Virginia L. Ernster, "Mixed Messages," p. 335-40. On Canada, see Rob Cunningham, Smoke and Mirrors: The Canadian Tobacco War (Ottawa: International Development Research Centre, 1996), p. 14.

8 Although we focus upon elite culture, the values were quickly disseminated to and adopted by women of other classes. Suzanne Marchand discusses this within the context of Quebeçois women in her excellent examination of La Revue Moderne, a middle-class francophone popular magazine, in the interwar period. See Suzanne Marchand, Rouge à Lèvres et Pantalon (Montreal: Hurtubise, 1997).

9 Henry Pringle, "High Hat," Scribner's, 104 (July 1938): 19. See Theodore Peterson, Magazines in the Twentieth Century (Urbana: University of Illinois Press, 1964), p. 266-67.

10 Peterson, Magazines in the Twentieth Century, p. 267.

11 Vogue absorbed the political review magazine, Vanity Fair, in 1936. James Playter Wood, Magazines in the United States, 2d ed. (N.Y.: Ronald Press, 1956), p. 129.

12 Canadian magazine circulation figures for the beginning of the century are difficult to determine. However, by the 1920s, the sales in Canada of popular American magazines such as Saturday Evening Post, Ladies Home Journal and Vogue totalled more (50 million in 1926) than all Canadian magazines combined. Mary Vipond, "Canadian Nationalism and the Plight of Canadian Magazines in the 1920s," Canadian Historical Review 58, 1 (March 1977): 43.

13 Mary Ellen Zuckerman, A History of Popular Women's Magazines in the United States, 1792-1995 (Westport: Greenwood Press, 1998), p. 115, 128, 164.

14 Edna Woolman Chase and Ilka Chase, Always in Vogue (London: Gollancz, 1954), p. 130.

15 Chase and Chase, Always in Vogue, chapter 11. See also Jane Garrity, "Selling Culture to the 'Civilized': Bloomsbury, British Vogue, and the Marketing of National Identity," Modernism/modernity 6, 2 (1999): 34.

16 Valerie Korinek noted the gendered management at Chatelaine, Canada's leading woman's magazine, where the publishing and advertising divisions were headed by men and the editorial offices run by women. See Valerie J. Korinek, Roughing It in the Suburbs: Reading Chatelaine Magazine in the Fifties and Sixties (Toronto: University of Toronto Press, 2000), p. 69-70. One has only to examine the credit pages of contemporary women's magazines to determine that this division still exists.

17 Chase and Chase, Always in Vogue, chapter 11.

18 Chase and Chase, Always in Vogue, was reviewed in the Saturday Review, 30 October 1954. Quoted in Wood, Magazines, p. 129, n. 2.

19 By 1926, US Vogue's advertising revenues topped all major North American periodicals except Saturday Evening Post. See Zuckerman, Popular Women's Magazines, p. 115, 133. In 1930, US Vogue's paid circulation totalled 133,931, ten times less than Better Homes and Gardens, but the fashion magazine collected \$3,012,593 from advertisers, while Better Homes garnered \$500,000 less. Better Homes and Gardens' circulation was $1,390,660$ in 1930 , and its advertising revenue was $\$ 2,515,353$. David Reed, The Popular Magazine in Britain and the United States, 1880-1960 (Toronto: University of Toronto Press, 1997), p. 153-54. 
20 See, for instance, U.S. Vogue (1 July 1924), p. 17, 22 which advertised college preparatory schools ("Miss Beard's School [for] Art, Music, Domestic Arts and Sciences"), military academies ("Staunton... An Ideal Home School for Manly Boys") and religious, secular, health and specialized camps ("The Teela-Wooket Camps... Famous for fine saddle horses").

21 White, Women's Magazines, p. 94.

22 Rudy, Freedom to Smoke, p. 18-19.

23 Tate, Cigarette Wars, p. 96-97.

24 Tinkler, Smoke Signals, chap. 2.

25 "Paris Spring Forecast," U.S. Vogue (15 February 1924), p. 41. The other page of this fashion spread (p. 45) has a large drawing of a model with cigarette.

26 "Swinging movement distinguishes the dance frock from formal evening gown," U.S. Vogue (1 January 1925), p. 34.

27 British Vogue (late June 1920), p. 92.

28 "Perfumed Moments" advert, British Vogue (July 1924), p. viii.

29 "De Reszke Cigarettes" advert, British Vogue (early July 1920), inside front cover.

30 Tate, Cigarette Wars, p. 105.

31 "Pall Mall" advert, U.S. Vogue (15 February 1924), p. 97.

32 "Pall Mall" advert, U.S. Vogue (15 April 1924), p. 104.

33 According to Lorraine Greaves, "the number of women using cigarettes has been significant in industrial countries only since the Second World War." See Smoke Screen, p. 18. See also U.S. Department of Health and Human Services, "Reducing Tobacco Use: A Report of the Surgeon General," (Washington: U.S. Government Printing Office, 2000), p. 37.

34 The standard in this respect was Lydia Pinkham's Vegetable Compound. See Sarah Stage, Female Complaints: Lydia Pinkham and the Business of Women's Medicine (N.Y.: W.W. Norton, 1979).

35 "Camels" advert, U.S. Vogue (15 April 1934), (after p. 72).

36 "Listerine Tooth Paste" advert, U.S. Vogue (15 March 1935), p. 1.

37 "Hawaii-Matson Line" advert, U.S. Vogue (1 January 1934), inside front cover.

38 U.S. Vogue (1 January 1934), p. 26-27. See also p. 33.

39 U.S. Vogue (1 January 1934), p. 39.

40 "Nicotined Lady," U.S. Vogue (15 October 1934), p. 41.

41 "Tragedies of the current mode," U.S. Vogue (1 February 1934), p. 42.

42 "Before Soup and After Nuts," U.S. Vogue (15 February 1934), p. 56. This photograph also appeared in British Vogue in an article recommending similar British products. See "Bridge Parties," British Vogue (13 June 1934), p. 82.

43 "Spud" advert, U.S. Vogue (15 April 1934).

44 "Finnigans" advert, British Vogue (13 June 1934), p. 40; "Monte Carlo Beach," British Vogue (11 July 1934), p. 34. See also 13 June 1934, p. 23.

45 British Vogue (7 March 1934), p. 112.

46 British Vogue (13 June 1934), p. 82.

47 British Vogue (11 July 1934), p. 13.

48 British Vogue (11 July 1934), p. 54.

49 British Vogue (10 January 1934), p. 47.

50 British Vogue (3 October 1934), p. 104-5.

51 British Vogue (2 May 1934), p. 111.

52 White, Women's Magazines, p. 105.

53 White, Women's Magazines, p. 93.

54 See Tinkler, "Refinement and Respectable Consumption," p. 342-60.

55 U.S. Vogue (October 1934), p. 41-43.

56 See, for instance, Carroll Smith-Rosenberg, "Discourses of Sexuality and Subjectivity: The New Woman, 1870-1936," in Martin Bauml Duberman, Martha Vicinus and George Chauncey, Jr., ed., Hidden from History: Reclaiming the Gay and Lesbian Past, (NY: New America Library, 1989). On smoking and the stereotype of the English lesbian, see Laura Doan, Fashioning Sapphism. The Origins of a Modern English Lesbian Culture (New York: Columbia University Press, 2001). 
57 Tinkler, Smoke Signals, p. 31-32.

58 "Worn-out country dames with clay pipes" were mentioned in British anti-tobacco tracts. See Hilton, Smoking in British Popular Culture, p. 143.

59 See S. Foster Damon, Amy Lowell. A Chronicle with Extracts from Her Correspondence (North Haven, Conn.: Shoe String Press, 1935, 1966); and Lillian Faderman, "CigarSmoking Sappho: Lesbian Laureate Amy Lowell Took Her World by Storm," Advocate, 13 February 1990. Many thanks to Terri Doughty and Marni Stanley of Malaspina's English Department for their boundless knowledge of all things literary.

60 Queen Marie of Romania, The Story of My Life (N.Y.: Charles Scribner's Sons, 1934).

61 Marie [Pavlovna], Grand Duchess of Russia, Education of a Princess: A Memoir (1930, reprinted Kessinger Press, 2005). There also, of course, was the continuing fascination with the legend of Anastasia, youngest daughter of the slain Tsar Nicholas II, and Anna Anderson's claim to be the lost princess.

62 Theda Bara (Theodosia Goodman)'s films included "La Belle Russe" (1919) and "The Tiger Woman" (1917), in which she portrayed Princess Petrovich, the evil vamp.

63 Pola Negri (Barbara Apollina Chalupiec)'s films included "A Woman Commands" (1932), "The Woman from Moscow" (1928), and "A Woman of the World" (1925).

64 Tinkler, "Refinement and Respectable Consumption," p. 343.

65 "Marlboro" advert, U.S. Vogue (15 May 1934), p. 119.

66 "Marlboro" advert, U.S. Vogue (15 July 1934), p. 76.

67 Tinkler, "Refinement and Respectable Consumption," p. 342-60.

68 'Spud" adverts, U.S. Vogue (15 March 1934), p. 95; (15 September 1934), p. 105; and (15 October 1934), p. 104.

69 John P. Marquand, "So Little Time," U.S. Vogue (1 April 1944), p. 79.

70 See "Marlboro" advert, U.S. Vogue (1 February 1944), p. 116.

71 "Marlboro" adverts, U.S. Vogue (15 February 1944), p. 104; and (1 June 1944, p. 170).

72 "Chesterfields" advert, U.S. Vogue (15 April 1944) p. 140.

73 "Silhouette de Luxe" advert, British Vogue (June 1944), p. 7.

74 "Sumrie" advert,' British Vogue (February 1944), p. 73. See also (April 1944), p. 31 and (September 1944), p. 28.

75 British Vogue (June 1944), p. 78.

76 British Vogue (January 1944), p. 12.

77 "Three Castles" advert, British Vogue (June 1944), p. 78.

78 Penny Tinkler, "Red Tips for Hot Lips: Advertising Cigarettes for Young Women in Britain, 1920-1970," Women's History Review 10, 2 (2001a): 249-72.

79 Wald et al., UK Smoking Statistics, p. 35, Table 4.1.2.

80 British Vogue (February 1954), p. 109.

81 "Union-Castle" advert, British Vogue (January 1954), p. 85.

82 "State Express 555" advert, British Vogue (September 1954), p. 181.

83 British Vogue (March 1954), p. 163.

84 See for example British Vogue (March 1954), p. 230 and (September 1954), p. 181.

85 "Ronson," advert, British Vogue (April 1954), p. 217.

86 British Vogue (1 April 1964), p. 93-94; (May 1964), p. 76; and (June 1964), p. 109.

87 British Vogue (June 1964); and (January 1964) p. 16.

88 Tinkler, Smoke Signals, p.187-94.

89 Wald et al., UK Smoking Statistics, p. 35, Table 4.1.2.

90 Tinkler, Smoke Signals, p. 189-92.

91 For example, "Player's" advert, British Vogue (June 1964), p. 96.

92 Tinkler, "Red Tips," p. 257.

93 Wald et al., UK Smoking Statistics, p. 62, Table 5.2. In Britain, smoking did not decline among women from lower social-class groups until the mid-1970s.

94 "Smartaire" advert, U.S. Vogue (15 January 1964), p. 34.

95 "Eastern Air Lines/Burdine's" advert, U.S. Vogue (I January 1964), p. 35.

96 "Cole of California" advert, U.S. Vogue (1 January 1964) p. 24. 
97 U.S. Vogue (1 April 1964), p. 136.

98 George Orwell, "It Looks Different from Abroad," New Republic 115 (2 December 1946), p. 726. See Peterson, Magazines in the Twentieth Century, p. 268.

99 See for instance U.S. Vogue (15 April 1924), p. 47.

100 "Dainty Lingerie from New York Shops," U.S. Vogue (15 January 1924), p. 68.

101 "Paris holds the mirror up to fashion," U.S. Vogue (15 April 1924), p. 47. This is followed by an article on dieting on page 70 .

102 "Entertaining Gossip," U.S. Vogue (15 January 1934).

103 "How They Do It," U.S. Vogue (15 February 1934), p. 36-37.

104 U.S. Vogue (1 July 1924), p. 1. See also "Marian Jacks" advert, U.S. Vogue (15 June 1934), p. 21; "Foundettes by Munsingwear" advert, U.S. Vogue (1 March 1935); p. 165 and "Carter's Mouldette-Actively yours for Kitten Hips" advert anthropomorphized a kitten dancing and rolling in a corset, and then washing it. U.S. Vogue (15 January 1944).

105 "Foundettes by Munsingwear" advert, U.S. Vogue (1 March 1935), p. $16 S$.

106 Valerie Steele, Fashion and Eroticism: Ideals of Feminine Beauty from the Victorian Era to the Jazz Age (Oxford: Oxford University Press, 1985). This was also the case in the US, see Lois Banner, American Beauty (Chicago: University of Chicago Press, 1984).

107 British Vogue (7 March 1928), p. 96.

108 British Vogue (early April 1918), p. viii.

109 See Christopher Breward, The Culture of Fashion (Manchester: Manchester University Press, 1995).

110 British Vogue (20 February 1935), p. 63.

111 "Berlei" advert, British Vogue (3 October 1934), p. 44.

112 Ernster, "Mixed Messages," 1985.

113 For example, Daily Express, (4 November 1928), p. 19; (27 November 1928), p. 3 ; (14 January 1930), p. 2; and (28 January 1930), p. 2.

114 "Plan Your Weight," U.S. Vogue (1 January 1944); and (1 May 1944).

115 "Ayds" advert, U.S. Vogue (1 January 1944), p. 63 and (July 1944), p. 138.

116 "Marlboro" advert, U.S. Vogue (15 September 1944), p. 195.

117 "Saks Fifth Avenue/ Capri Original," advert, U.S. Vogue (1 November 1944), p. 22.

118 "Hansen" advert, U.S. Vogue (15 March 1954), p. 149. A 1940s example is "Fownes Gloves" advert, U.S. Vogue (1 September 1944), p. 205.

119 "Metrecal," U.S. Vogue (15 April 1964), p. 34

120 "The Chanel Look," British Vogue (March 1954), p. 135.

121 British Vogue (February 1954), p. 66-67.

122 British Vogue (August 1954), p. 72.

123 Tinkler, "Red Tips," p. 263.

124 "Toledo" advert, British Vogue (August 1964), p. 24.

125 For example, British Vogue (late June 1919), p. lviii.

126 "De Reszke" advert, British Vogue (early May 1919), inside front cover; and (early June 1919), inside front cover. See also "Miss Peggy Kurton" and (early July 1919), inside front cover.

127 "Fair comment on men, maids and manners," British Vogue (early March 1924), p. 27.

128 "Bachelor's" advert, British Vogue (7 March 1934), p. 138 and (1934), p. 50.

129 For example, "Bachelor's" advert, British Vogue (9 January 1935), p. 67.

130 This was consistent with advertising in other British women's magazines from the 1930s; see for example adverts for de Reszke Minors in Woman in 1939 that featured middle-class British actors and personalities.

131 Steele, Fashion and Eroticism, p. 329.

132 British Vogue (late June 1920), p. 104.

133 See for instance, "Camels" advert, U.S. Vogue (15 April 1934) as well as several dowagers' testimonials for Dodge automobiles, U.S. Vogue (15 May 1934), p. 115.

134 "Princessa Foundations" advert, U.S. Vogue (1 April 1934), p. 110; and "Diana" advert, (15 October 1934), p. 111. 
135 Sylvia Thompson, "Salon," U.S. Vogue (15 March 1934), p. 39, 78.

136 "Bonwit Teller" advert, U.S. Vogue (1 November 1944), p. 129. See also "Lord \& Taylor" advert, U.S. Vogue (1 September 1954), p. 7.

137 "Care of the Figure," U.S. Vogue (1 November 1944).

138 "March Fashion," U.S. Vogue (1 March 1954), p. 158.

139 U.S. Vogue 123 (15 February 1954), p. 85.

140 In the earliest adverts to appear in US Vogue, women were not portrayed as smokers but, instead, as domesticated and servile, either to a father figure or men of superior social standing.

141 The model closest to her appears to be attempting to avoid getting burnt by her lit cigarette. U.S. Vogue (15 April 1924), p. 75.

142 "Paris Openings," U.S. Vogue (1 March 1935), p. 46.

143 U.S. Vogue (January 1934), p. 72. See also (1 March 1935), p. 46 and (1 August 1934).

144 "Vogue's Smart Economies," U.S. Vogue (February 1934), p. 62.

145 "Couturier Designs for Practical Dressmaking," U.S. Vogue (15 February 1934).

146 "De Reszke cigarettes" adverts, British Vogue (early June 1919), (early July 1919), (early May 1919). The link between smoking and feminine modernity was reiterated in other women's magazines for readers lower down the social scale, although in these magazines the modernity of smoking was conveyed principally through fiction and features than through cigarette advertising. See Penny Tinkler, "Rebellion, Modernity and Romance: Smoking as a Gendered Practice in Popular Young Women's Magazines, Britain 1918-1939," Women's Studies International Forum, 24 (2001b), p. 1-12.

147 "Player's" advert, British Vogue (4 March 1930), p. 84.

148 "Player's" advert, British Vogue (5 February 1930), p. 79.

149 "De Reszke" advert, British Vogue (early July 1919), inside front cover. Rivalry for men might have reflected the reality of a dearth of eligible young men in the immediate postwar era.

150 See examples cited in note 74.

151 "American Pioneer," U.S. Vogue (1 February 1944), p. 82.

152 See, for example, Roberta G. Ferrence, Deadly Fashion: The Rise and Fall of Cigarette Smoking in North America (N.Y.: Garland, 1989); Stanton A. Glantz et al., The Cigarette Papers (Berkeley: University of California Press, 1996); Richard Kluger, Ashes to Ashes: America's 100 Year Cigarette War, the Public Health, and the Unabashed Triumph of Philip Morris (N.Y.: Alfred A. Knopf, 1996); and Hilton, Smoking in British Popular Culture.

153 "Camels-Women in the War" adverts, U.S. Vogue (1 February 1944), p. 116; (July 1944), p. 144; (1 October 1944), p. 206; (1 May 1944) p. 184; (1 September 1944), p. 228; and (1 November 1944), p. 196.

154 "Miss Cricketeer" advert, U.S. Vogue (15 January 1944), p. 94.

155 "Marlboro" advert, U.S. Vogue (15 January 1944), p. 87.

156 "Pond's" advert, U.S. Vogue (1 January 1944), p. 75.

157 "Cheney Fabrics," U.S. Vogue (1 August 1944), p. 32; and "Marlboro" advert U.S. Vogue (1 August 1944).

158 U.S. Vogue (1 May 1944).

159 "Marlboro" advert, U.S. Vogue (15 May 1944), p. 133.

160 "Gossard" advert, U.S. Vogue (15 May 1944), p. 35.

161 "Helen of Hollywood" advert, U.S. Vogue (15 February 1944), p. 20 and (15 April 1944), p. 40.

162 See for instance "Marlboro" adverts, U.S. Vogue (15 Mach 1944), p. 134; and (15 September 1944), p. 195.

163 The emphasis among American market researchers upon women's "intuition" and "irrationality" is described in Lizabeth Cohen, A Consumers' Republic: The Politics of Mass Consumption in Postwar America (N.Y.: Alfred A. Knopf, 2003), p. 314.

164 “The Lazy Woman's Guide to Exercise," U.S. Vogue (1 March 1954), p. 80.

165 "More Taste than Calories,' U.S. Vogue (15 February 1954), p. 88. 
166 "Munsingwear Nylons" advert, U.S. Vogue (1 April 1954), p. 14.

167 "Humming Bird Stockings" advert, U.S. Vogue (1 April 1954), p. 64.

168 "Jaunty Junior" advert, U.S. Vogue (1 February 1954), p. 67.

169 U.S. Vogue (15 May 1954), p. 86. See also (1 May 1954), p. 159 and (January 1954), p. 81. The post-World War II segmentation of the American consumer markets by gender, class and race is discussed in Cohen's A Consumers' Republic, p. 292-331.

170 "Candidates for Prizes," U.S. Vogue (1 May 1954), p. 135; and "See Them Now," U.S. Vogue (1 February 1954), p. 145.

171 "Bernhard Altmann" advert, U.S. Vogue (1 September 1954), p. 85. See also (15 February 1954), p. 58 and "Haig \& Haig" advert, U.S. Vogue (15 September 1964), p. 37.

172 Ernster, "Mixed Messages," 1985. By the 1970s and 1980s, under the editorship of Grace Mirabella, Vogue was one of the few companies who acknowledged the health risks of smoking. Mirabella was married to a thoracic surgeon, William G. Cahan, who was an anti-tobacco activist.

173 See for example U.S. Vogue (1 May 1954), p. 126-This picture also appears in British Vogue-(1 March 1954), p. 103; (January 1954), p. 97; (July 1954), p. 86; (15 August 1954), p. 10; and (June 1954), p. 40.

174 Betty Freidan, The Feminine Mystique (New York: Dell, 1963).

175 "Player's No. 3" advert, British Vogue (March 1954), p. 230; and (January 1954), p. 85.

176 "State Express 555" advert, British Vogue (September 1954), p. 181.

177 See the identical shot of a woman inhaling a cigarette in British Vogue (August 1954), p. 72 and U.S. Vogue (1 May 1954), p. 126.

178 "Brenner" advert, British Vogue (March 1954), p. 46. 